\title{
CRESCIMENTO E CONCENTRAÇÃO DE NUTRIENTES E DE SÓDIO EM Q Qigna sinensis (L.) ENDL. "SERIDÓ" CULTIVADA EM SOLUÇÃO NUTRITIVA COM VARIAÇÃO NO FORNECIMENTO DE POTÁSSIO, CÁLCIO, MAGNÉSIO E SÓDIO
}

\section{Zelson Tenório \\ - Engenheiro Agrônomo - \\ EMBRAPA}

Tese apresentada à Escola Superior de Agricultura "Luiz de Queiroz", da Universidade de Sáo Paulo, para obtenção do título de Doutor em Agronomia na área de Solos e Nutrição de Plantas.

\author{
PIRACICABA \\ Estado de São Paulo - Brasil \\ Novembro, 1981
}


Aos meus pais e irmãos

ofereço

A Marigia,

Vanessa, Fātima e Zelson Luiz,

dedico 
HOMENAGEM $\AA$ ESCOLA SUPERIOR DE AGRICULTURA "LUIZ DE QUEIROZ", USP, PIRACICABA, S.P. PELOS OITENTA ANOS DE EXISTENCIA 
Ao Prof. Dr. Josē Renato Sarruge

Ao Prof. Or. Henrique Paulo Haag

Ao Prof. Dr. Antonio Roque Dechen

Ao Prof. Dr. José Vitaliano de Carvalho Rocha Filho

Ao Prof. Dr. Gilberto Diniz de Oliveira (in memorium)

Aos funcionārios do Setor de Nutrição Mineral de Plantas do Departamento de Quĩmica da Escola Superior de Agricultura "Luiz de Queiroz"

A Escola Superior de Agricultura "Luiz de Queiroz". Universidade de São PauTo

A Empresa Brasileira de Pesquisa Agropecuäria (EMBRAPA) 


\section{INDICE}

Pāgina

LISTA DE TABELAS

RESUMO

1. INTRODUÇATO

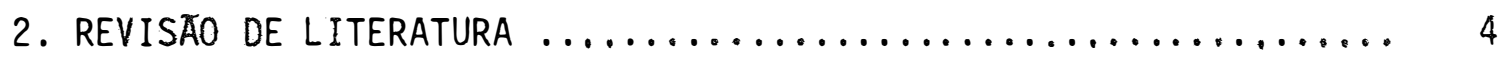

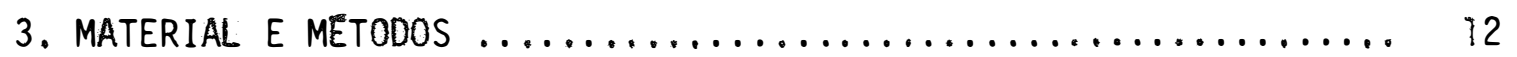

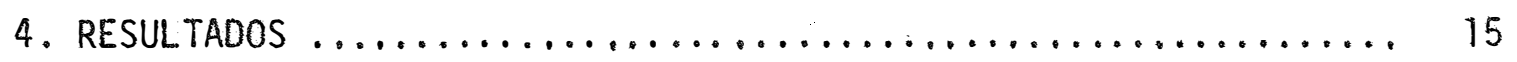

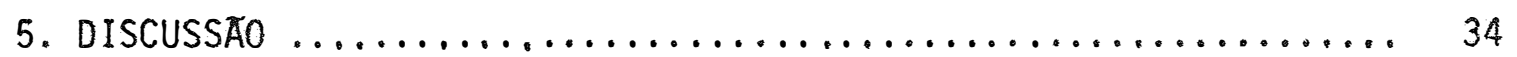

5.1. Produção de Matéria Seca das Folhas e Caules ........... 34

5.2. Concentração de Nutrientes na Matéria Seca em Função das doses de Potāssio, Cālcio, Magnésio e Södio ..... 38

5.2.1. Concentração de Nitrogēnio ................ 38

5.2.2. Concentração de Fösforo ................. 41

5.2.3. Concentração de Potāssio .................. 44

5.2.4. Concentração de Cālcio ................... 47

5.2.5. Concentração de Magnēsio .................. 51

5.2.6. Concentração de Enxōfre .................... 55

5.2.7. Concentração de Boro .................... 60

5.2.8. Concentração de Cobre ................... 62

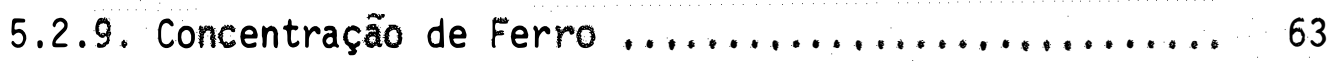

5.2.10. Concentração de Manganēs ................. 65

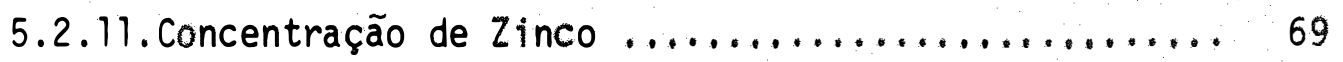

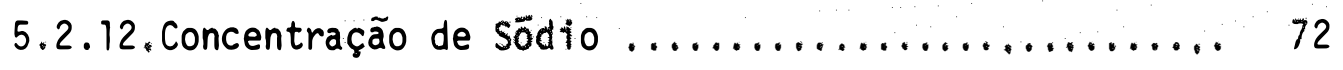




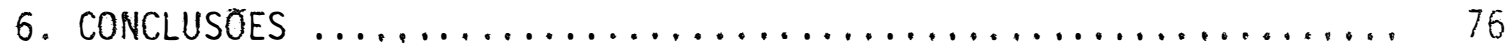

6.1 . Matéria Seca $\ldots \ldots \ldots \ldots \ldots \ldots \ldots \ldots \ldots \ldots \ldots \ldots \ldots \ldots$

6.2. Concentração de Nutrientes $\ldots \ldots \ldots \ldots \ldots \ldots \ldots \ldots \ldots \ldots$

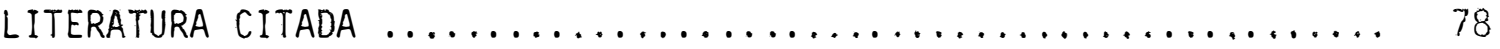


LISTA DE TABELAS

Tabela no

Pāgina

1 Produção de matēria seca ( $g / p$ lanta) nas folhas e caules de Vigna sinensis (L.) Endl, em função dos $n i$ veis de potāssio, cālcio, magnésio e sōdio ........... 16

2 Concentração de nitrogēnio (\%) na matēria seca das fo Thas e caules de Vigna sinensis (L.) Endl. ......... 17

3 Concentração de fósforo (\%) na matéria seca das foThas e caules de Vigna sinensis (L.) Endl. .......... 18

4 Concentração de potássio (\%) na matēria seca das foThas e caules de Vigna sinensis (L.) Endl. .......... 19

5 Concentração de cáicio (\%) na matēria seca das fol has e caules de Vigna sinensis (L.) Endl. ............. 20

6 Concentração de magnésio (\%) na matēria seca das foThas e caules de Vigna sinensis (L.) Endl. ......... 21

7 Concentração de enxōfre (\%) na matēria seca das foThas e caules de Vigna sinensis (L.) End $1, \ldots . . . \ldots 22$

8 Concentração de boro (ppm) na matēria seca das fol has e caules de Vigna sinensis (L.) Endl. .............. 23

9 Concentração de cobre (ppm) na matëria seca das foThas e caules de Vigna sinensis (L.) Endl. .......... 24

10 Concentração de ferro (ppm) na matëria seca das foThas e caules de Vigna sinensis (L.) Endl. .......... 25 
11 Concentração de manganēs (ppm) na matéria seca das folhas e caules de Vigna sinensis (L.) Endl.

12 Concentração de zinco (ppm) na matēria seca das fo Ihas e caules de Vigna sinensis (L.) Endl. ..........

13 Concentração de sōdio (ppm) na matēria seca das fo Ihas e caules de Vigna sinensis (L.) Endl. ..........

14 Resumo das anālises de variāncia da produção de ma téria seca (g/planta) das fol has e caules de Vigna sinensis (L.) Endl.

15 Resumo das anālises da variāncia das concentrações (\%) de $N, P, K, C a, M g$ e $S$ na matéria seca das foIhas de Vigna sinensis (L.) Endl.

16 Resumo das anālises da variāncia das concentrações (\%) de $N, P, K, C a, M g$ e $S$ na matéria seca dos cau les de Vigna sinensis (L.) Endl.

17 Resumo das anālises da variāncia das concentrações (ppm) de $\mathrm{B}, \mathrm{Cu}, \mathrm{Fe}, \mathrm{Mn}, \mathrm{Zn}$ e $\mathrm{Na}$ na matēria seca das folhas de Vigna sinensis (L.) Endl. .............

18 Resumo das anālises da variāncia das concentrações (ppm) de $\mathrm{B}, \mathrm{Cu}, \mathrm{Fe}, \mathrm{Mn}, \mathrm{Zn}$ e $\mathrm{Na}$ na matéria seca dos caules de Vigna sinensis (L.) Endl.

19 Produção de matéria seca ( $g$ ) das folhas de Vigna sinensis (L.) Endl., em função das doses de potássio, cālcio e magnésio na solução nutritiva. 
20 Produção de matēria seca dos caules de Vigna sinensis (L.) Endl., em função das doses de potāssio na solução nutritiva $\ldots \ldots \ldots \ldots \ldots \ldots \ldots \ldots \ldots \ldots \ldots \ldots \ldots \ldots \ldots \ldots \ldots$

21 Produção de matéria seca dos caules de Vigna sinensis (L.) Endl.. em função das doses de cálcio na solução nutritiva

22 Produção de matéria seca dos caules de Vigna sinensis ( $L$. ) Endl., em função das doses de magnēsio na solução nutritiva $\ldots \ldots \ldots \ldots \ldots \ldots \ldots \ldots \ldots \ldots$

23 Concentração de nitrogēnio na matéria seca das foThas e caules de Vigna sinensis (L.) Endl., em função das doses de potāssio na solução nutritiva ........

24 Concentração de nitrogēnio na matéria seca dos caules de Vigna sinensis (L.) Endl., em função das do

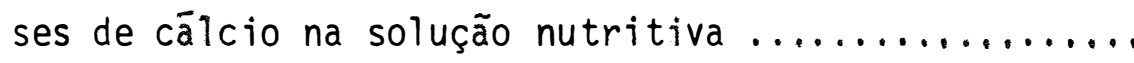

25 Concentração de nitrogēnio na matēria seca dos caules de Vigna sinensis (L.) Endl., em função das do

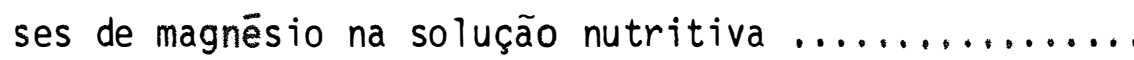

26 Concentração de nitrogēnio na matēria seca dos caules de Vigna sinensis (L.) Endl., em função das do-

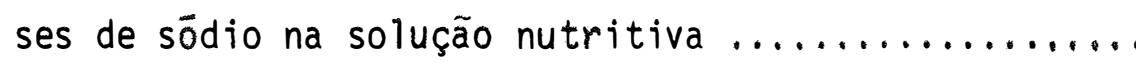

27 Concentração de fōsforo (\%) na matēria seca das foThas de Vigna sinensis (L.) Endl., em função das doses de potāssio e cālcio na solução nutritiva ......... 
28 Concentração de fósforo (\%) na matéria seca dos cau les de Vigna sinensis (L.) End?., em função das doses de potássio, cālcio e magnésio na solução nu-

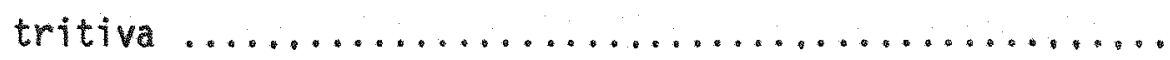

29 Concentração de potāssio na matēria seca das folhas de Vigna sinensis (L.) Endl., em função de doses de

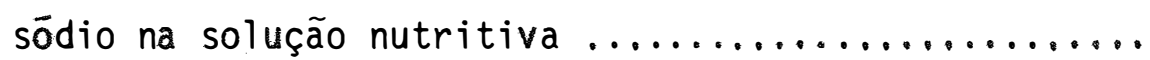

30 Concentração de potāssio (\%) na matéria seca das fo Thas de Vigna sinensis ( $L$. ) Endl., em função das do ses de potássio e cáicio na solução nutritiva ........

31 Concentração de potássio (\%) na matéria seca dos caules de Vigna sinensis ( $L$.) Endl., em função das doses de potássio e cālcio na solução nutritiva .......

32 Concentração de potāssio (\%) na matēria seca dos caules de Vigna sinensis ( $L$.) Endl., em função das doses de cálcio e magnésio na solução nutritiva .......

33 Concentração de cālcio (\%) na matēria seca das foThas de Vigna sinensis ( $L$.$) Endl., em função das do$ ses de potāssio e cálcio na solução nutritiva .........

34 Concentração de cālcio na matéria seca dos caules de Vigna sinensis (L.) Endl., em função das doses de sōdio na solução nutritiva .................

35 Concentração de cālcio (\%) na matēria seca dos caules de Vigna sinensis (L.) Endl., em função das doses de potássio, cálcio e magnésio na solução nu-

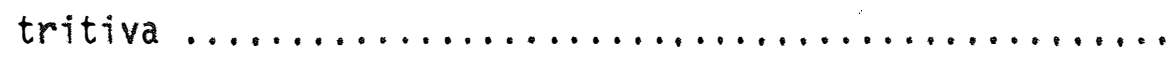


36 Concentração de magnésio na matéria seca das foThas de Vigna sinensis ( $L$. ) Endl., em função das doses de cālcio na solução nutritiva ............. 5 ?

37 Concentração de magnésio (\%) na matéria seca das folhas de Vigna sinensis ( $L$.) End1., em função das doses de potássio e magnésio na solução nutritiva ......

38 Concentração de magnésio (\%) na matéria seca dos caules de Vigna sinensis (L.) Endl., em função das doses de cálcio e magnésio na solução nutritiva .......

39 Concentração de magnésio (\%) na matéria seca dos caules de Vigna sinensis ( $L$.) Endl., em função das doses de potássio e sōdio na solução nutritiva.

40 Concentração dè enxōfre na matéria seca das folhas de Vigna sinensis (L.) Endl., em função das do-

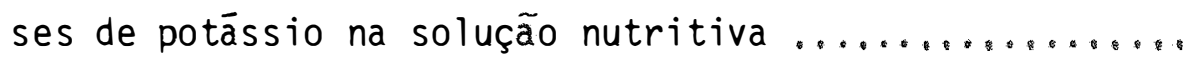

41 Concentração de enxōfre na matéria seca das folhas de Vigna sinensis (L.) Endl.. em função das doses de cálcio na solução nutritiva ................ 56

42 Concentração de enxōfre na matēria seca das folhas de Vigna sinensis (L.) Endl., em função das doses

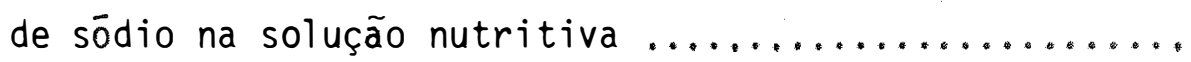

43 Concentração de enxōfre (\%) na matēria seca dos caules de Vigna sinensis (L.) End1., em função das doses de potássio e sōdio na solução nutritiva ........ 
44 Concentração de enxōfre (\%) na matéria seca dos cau les de Vigna sinensis ( $L$. ) Endl., em função das doses de potássio, cālcio e magnésio na solução nu-

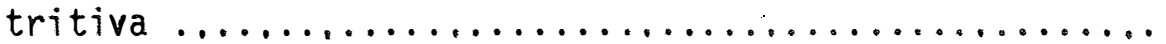

45 Concentração de boro na matéria seca dos caules de Vigna sinensis (L.) End1., em função das doses de sōdio na solução nutritiva

46 Concentração de boro (ppm) na matéria seca dos caules de Vigna sinensis (L.) Endl., em função das doses de potássio, cālcio e magnésio na solução nutritiva

47 Concentração de cobre na matēria seca dos folhas e caules de Vigna sinensis (L.) Endl., em função das

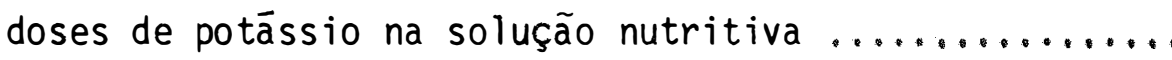

48 Concentração de ferro (ppm) na matéria seca das foThas de Vigna sinensis (L.) Endl., em função das do ses de potāssio e cālcio na solução nutritiva ..........

49 Concentração de ferro (ppm) na matéria seca das foThas de Vigna sinensis (L.) Endl., em função das do ses de potāssio e magnésio na solução nutritiva .......

50 Concentração de ferro na matéria seca dos caules de Vigna sinensis (L.) Endl., em função das doses de potāssio na solução nutritiva ................

51 Concentração de manganès na matéria seca das fol has de Vigna sinensis (L.) Endl., em função das doses de potāssio na solução nutritiva $\ldots \ldots \ldots \ldots \ldots \ldots \ldots$ 
52 Concentração de manganēs (ppm) na matēria seca das folhas de Vigna sinensis (L.) Endl., em função das doses de cálcio e magnésio na solução nutritiva .......

53 Concentração de manganēs (ppm) na matéria seca dos caules de Vigna sinensis ( $L$.) Endl., em função das doses de cálcio e magnésio na solução nutritiva ......

54 Concentração de manganēs ( $\mathrm{ppm}$ ) na matéria seca dos caules de Vigna sinensis (L.) Endl., em função das doses de potāssio e sōdio na solução nutritiva ........

55 Concentração de zinco na matéria seca das folhas e caules de Vigna sinensis (L.) Endl., em função das doses de cálcio na solução nutritiva ............... 70

56 Concentração de zinco na matéria seca dos caules de Vigna sinensis ( $L$. .) Endl., em função das doses de potāssio na solução nutritiva ..................

57 Concentração de zinco na matēria seca dos caules de Vigna sinensis (L.) Endl., em função das doses de magnēsio na solução nutritiva ...................

58 Concentração de sōdio na matēria seca das folhas de Vigna sinensis (L.) End1., em função das doses de sōdio na solução nutritiva ......................

59 Concentração de sōdio (ppm) na matéria seca das fo Thas de Vigna sinensis ( $L$.) Endl., em função das doses de potássio e cálcio na solução nutritiva... 
60 Concentração de sōdio na matēria seca dos caules de Vigna sinensis (L.) Endl., em função das doses de magnésio na solução nutritiva ................ 74

61 Concentração de sōdio (ppm) na matéria seca dos caules de Vigna sinensis (L.) Endl., em função das doses de potássio, cālcio e sōdio na solução

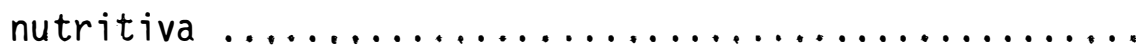


CRESCIMENTO E CONCENTRAÇAOO DE NUTRIENTES E DE SODDIO EM Vigna sinensis (L.) ENDL. 'SERIDO' CULTIVADA EM SOLUÇAOO NUTRITIVA COM VARIAÇÃO NO FORNECIMENTO DE POTASSIO, CALLCIO, MAGNESIO E SŌDIO

Candidato: Zelson Tenörio Orientador: Josē Renato Sarruge

RESUMO

Plantas de Vigna sinensis (L.) Endl., 'Seridó', foram cult ivadas em casa de vegetação da Escola Superior de Agricultura "Luiz de Queiroz", Piracicaba (SP), em quartzo moido, irrigadas com soluções nutritivas conforme SARRUGE (1975), com o objetivo de identificar as interrelações potássio, cālcio, magnēsio e sōdio na produção de matéria seca das plantas e de determinar a dependēncia entre a acumulação dos nutrientes e do sōdio nas plantas e os tratamentos propostos.

0 delineamento experimental foi um fatorial $3^{4}$, estudando-se o potāssio, cālcio, magnēsio e sōdio nas concentrações de 0 - $117-234$ ppm de potássio; $0-100-200$ ppm de cálcio; 0-24-48 ppm de magnésio e 0 - 92 - 184 ppm de sōdio.

A colheita dos primeiros tratamentos teve início quarenta e um dias apōs o plantio. As plantas coletadas foram separadas em caules e folhas e determinaram-se os teores de nitrogēnio, fósforo, potāssio, cālcio, magnēsio, enxöfre, boro, cobre, ferro, manganēs, zinco e sōdio. 
Os resultados mostraram que:

- A máxima produção de matéria seca dos caules foi alcançada com concentrações de 117,100 e 24 ppm de potássio, cálcio e magnésio respectivamente, na solução nutritiva. Os aumentos de matéria seca das folhas provocados pela aplicação destes elementos, foram resultado de interação tripla entre os mesmos.

- Não foi possiviel detectar efeitos da aplicação de até 184 ppm de sōdio, na produção de matéria seca de qualquer parte da plan ta.

- A aplicação de potássio, cālcio, magnésio ou sōdio, au mentou a concentração do elemento em questão, na matéria seca dos caules e folhas das plantas.

- Os efeitos registrados pela aplicação de potássio na solução nutritiva, foram de diminuição das concentrações dos demais elementos na matéria seca das plantas, com exceção do enxōfre e ferro nas folhas e do boro nos caules.

- Os efeitos registrados pela aplicação de cálcio ou magnésio na solução nutritiva, foram de diminuição das concentrações dos demais elementos na matéria seca das plantas, com exceção do boro nos caules.

- 0 comportamento do sōdio aplicado à solução nutritiva, foi semelhante ao do cálcio ou magnésio, sendo registrado ainda, aumento da concentração de potássio nas folhas, quando o elemento em questão foi aplicado na dose de 184 ppm. 
GROWTH AND CONCENTRATIJN OF NUTRIENTS AND SODIUM IN COWPEA

(Vigna sinensis (L.) Endl.) VAR. SERIDO CULTIVATED IN

CULTURE SOLUTION WITH VARIATIONS IN POTASSIUM, CALCIUM, MAGNESIUM AND SODIUM SUPPLY

Candidate: Zelson Tenōrio Adviser: Josē Renato Sarruge

SUMMARY

In order to examine the relations amid the $\mathrm{K}, \mathrm{Ca}, \mathrm{Mg}$ and $\mathrm{Na}$ in the plant's dry matter production and to decide the dependence among the nutrients and $\mathrm{Na}$ accumulation in the plants as well as the proposed treatments, cowpeas (Vigna sinensis (L.) Endl.) 'Seridō' plants were cultivated in crushed quartz and irrigated with nutritive solutions according to SARRUGE (1975).

The experimental delineation was a $3^{4}$ factorial, had been studied $\mathrm{K}, \mathrm{Ca}, \mathrm{Mg}$ and $\mathrm{Na}$ in the following concentrations: 0-117-234 ppm of $\mathrm{K} ; 0-100-200 \mathrm{ppm}$ of $\mathrm{Ca} ; 0-24-48 \mathrm{ppm}$ of $\mathrm{Mg}$ and 0-92-184 ppm of $\mathrm{Na}$.

Forty one days later the plants were harvested. The collected plants were separated into stem and leaves. After that the concentrations in $\mathrm{N}, \mathrm{P}, \mathrm{K}, \mathrm{Ca}, \mathrm{Mg}, \mathrm{S}, \mathrm{B}, \mathrm{Cu}, \mathrm{Fe}, \mathrm{Mn}, \mathrm{Zn}$ and $\mathrm{Na}$ were determined by the conventional methods.

The attained results were: 
- The highest stems dry matter production was perceived by the following concentration of the elements in nutritive solutions: $117 \mathrm{ppm}$ of $\mathrm{K}, 100 \mathrm{ppm}$ of $\mathrm{Ca}$ and $24 \mathrm{ppm}$ of $\mathrm{Mg}$. The leaves dry matter improvements provoked by those elements resulted from a triple interaction among the above cited elements.

- It was impossible to detect the effects of the $\mathrm{Na}$ application on the dry matter production of any parts of the plant, even with the application of $184 \mathrm{ppm}$ of $\mathrm{Na}$ into the nutritive solution.

- The application of $\mathrm{K}, \mathrm{Ca}, \mathrm{Mg}$ or $\mathrm{Na}$ improved the respective concentration of the elements in the leaves and stem dry matter.

- The noticed effects of the Kapplication in nutritive solution was a decrease in the concentration of the elements, except $S$ and $F e$ concentration in the leaves and $B$ in the stem.

- In the same way the $\mathrm{Ca}$ or Mg application in the nutritive solutions showed a decrease in the concentrations of the remaining elements in the plants, save $B$ concentration in the stem.

- The application of $\mathrm{Na}$ had the same behavior as $\mathrm{Ca}$ or $\mathrm{Mg}$, being also registred a $K$ concentration improvement in the leaves, when this element was applied at $184 \mathrm{ppm}$ in the nutritive solution. 
1. INTRODUÇAOO

A linha de tendēncia de produção e ārea cultivada com feijão no Brasil, segundo JUNQUEIRA et alii (1972), cresceu praticamen te às mesmas taxas. De acordo com a FAO (1979), o rendimento mëdio de feijão no Brasil, alcançou naquele ano $519 \mathrm{~kg} / \mathrm{ha}$, com uma ārea cultivada de 4.212 .000 ha e uma produção de 2.187.000 toneladas.

No Brasil, são cultivadas duas espécies: o feijão comum (Phaselus vulgaris $L$. ) e o feijão macassar (Vigna sinensis ( $L$. ) Endl.), porém as estatísticas brasileiras não estabelecem limites entre as quantidades produzidas das duas espécies, embora MEDINA (1972), estima que aproximadamente $70 \%$ da produção de feijão da região Nordeste è do genero Vigna, conhecido popularmente no Brasil como feijão macassar, feijão de corda, feijão caupi e feijão baiano, sendo citado na literatura mundial com o nome comum de cowpea.

Originārios da Africa, segundo BURKART (1943), os feijões pertencentes a espécie Vigna sinensis, são cultivados no Brasil praticamente nas regiões Norte e Nordeste. Embora cultivados em escala 
relativamente modesta nas regiões tropicais e subtropicais, certamente os feijões pertencentes a essa espēcie, constituem alimento básico para milhões de pessoas dessas regiões, entre as qua is se encontra 0 Nordeste do Brasil, onde algodão e gado, como maiores empreendimentos, juntamente com lavouras consorciadas de milho e feijão macassar, repre senta uma das principais características da agricultura tradicional da região. Além disso, é cultivado em quase toda sua totalidade na região semi-ärida, cujos solos em grande parte, estão sujeitos a salinização.

WORD e SANDERS (1977), com base na hipótese da existência de substanciais deficiências nutricionais entre as famîlias de baixa renda, rurais e urbanas no Nordeste brasileiro, concluiram que o nivel de deficiéncia nutricional é severo para o homem do campo do sertão e os pobres da zona urbana do Nordeste. Por outro lado, o feijão macassar, constitui juntamente com a rapadura e a farinha de mandioca o alimento principal do homem do campo, sendo o feijão macassar, considerado por LEMOS e PONTE (1978), a principal fonte proteica vegetal para as populações nordestinas, principalmente aquelas de baixa renda.

A produtividade média do feijão macassar no Nordeste ainda è muito baixa. Segundo PAIVA (1971), no Estado do Cearā, o rendimento médio na ordem de $568 \mathrm{~kg} / \mathrm{ha}$, deve-se a pobreza natural dos so1os. Assim, o conhecimento dos problemas nutricionais desta cultura se reveste da maior importāncia, podendo contribuir para o aumento da sua produtividade, com reflexos na economia da região. 
Face ao exposto, foi conduzido o presente trabalho, com o objetivo de identificar as interrelações potāssio, cālcio, magnēsio e sōdio na produção de matēria seca das plantas de Vigna sinensis (L.) Endl., cultivado em solução nutritiva, bem como, determinar a dependēn cia entre a acumulação dos nutrientes e do södio nas plantas e os tratamentos propostos. 


\section{REVISÃO DE LITERATURA}

A nutrição do feijão Vigna sinensis (L.) Endl., não tem merecido a devida atenção por parte da comunidade científica mundial, inclusive do Brasil e do Nordeste em particular, onde a cultura se reveste de um significado muito especial, basicamente como principal fonte protéica para as populações de mais baixa renda. Caracterizado como produto alimentar de subsistência para as populações tropicais subdesenvolvidas, não sendo portanto, produto de exportação, torna-se compreensivel a escassez de literatura relacionada com os aspectos nutricionais da cultura.

SELLSCHOP (1962) relatou elevadas produções de cowpea em solos de alta fertilidade, porēm, as melhores produções de sementes são obtidas em solos menos férteis, ressaltando entretanto a importāncia do cālcio e fósforo, bem como de nitrogēnio e molibdēnio para a produção.

JACQUINOT (1967), através de um estudo comparativo entre crescimento e nutrição mineral de quatro varieades de Vigna 
unguiculata Walp., concluiu tratar-se de uma planta rica em nitrogênio. o qual se acumula principalmente nas folhas durante o ciclo vegetativo. O fósforo é absorvido em quantidades relativamente grandes, sendo $80 \%$ absorvido nos ūitimos 30 dias da fase vegetativa, absorve quantidades relativamente pequenas de enxōfre. E uma planta rica em potássio, parecendo ser capaz de aproveitar facilmente as reservas do solo, sendo satisfatōria a nutrição potássica em solo com baixo teor desse elemento. A porcentagem de absorção de cálcio é muito mais alta do que a taxa de crescimento, refletindo num aumento deste nutriente na planta, enquanto que o magnésio é absorvido principalmente no final do ciclo vegetativo. Segundo o autor, o equilíbrio entre potássio, cálcio e mag nédio, depende principalmente da idade da planta, sendo quase constante nas raĩzes e caules, porém se modifica muito nas folhas, devido em gran de parte a remoção do potássio e a acumulação progressiva de cálcio nas folnas.

Singh e Jain (1968), citados por STAMFORD (1978), na India, estudando o efeito do fósforo na absorção do nitrogēnio e fósforo em cowpea, cultivar Russian Giant, mostraram que os nīveis de nitrogênio e fósforo nas folhas aumentaram consideravelmente com o incremento dos niveis de $\mathrm{P}_{2} \mathrm{O}_{5}$ no solo.

STUART e REED (1969), nos Estados Unidos da América do Norte, desenvolvendo estudos básicos de fertilidade durante 2 anos, ut lizando 2 variedades de Vigna sinensis (L.) Endl., e värios nīveis de adubação NPK, observaram aumentos significativos no crescimento das plantas, resultantes do aumento das doses de aplicação de fósforo no 
solo, não sendo muito afetado o crescimento pela aplicação de nitrogēnio e potāssio. o conteúdo de fósforo e potāssio na planta, aumentou respectivamente com a aplicação de cada elemento no solo, sendo que a aplicação de fósforo, provocou diminuição nos nîveis de potássio nas plantas. A aplicação de nitrogênio aumentou o conteúdo de cálcio e mag nésio, ao passo que, a aplicação de potássio no solo, reduziu o conteúdo de cálcio e magnésio nas plantas.

PAIVA et alii (1971), através de estudo de adubação NPK com Vigna sinensis (L.) Endl., cultivar 'Seridō', em quatro localidades do Estado do Ceará, concluiram que o nitrogēnio provocou um aumento de 10 a 19\% na produção; o fósforo chegou a provocar um acréscimo de a té $136 \%$, não sendo registrado efeito significativo do potássio sobre o aumento de produção de grãos.

TAVORA et aliu (1971), estudando as respostas do feijão cowpea, variedade Seridó, à diferentes doses de adubação fosfatada $\left(0,25,50,75\right.$ e $\left.100 \mathrm{~kg} \mathrm{P}_{2} \mathrm{O}_{5} / \mathrm{ha}\right)$, constataram haver diferenças significativas entre os tratamentos. Nas doses mais elevadas de aplicação de fósforo, ou seja, 75 e $100 \mathrm{~kg} P_{2} \mathrm{O}_{5} /$ ha, houve diminuição na produção em comparação com a dosagem de $50 \mathrm{~kg} / \mathrm{ha}$.

WORLEY et alii (1971), nos Estados Unidos da América do Norte, estudando o efeito do nitrogênio, fósforo e potāssio na cultura do cowpea, por um perïodo de 4 anos consecutivos, obtiveram a maior pro dução média com o suprimento no solo de NPK nas doses de 55 - 24 - 46 quilos de NPK/ha. Com base nos resultados obtidos, os autores sugerem as doses 28 - 55 quilos de N/ha, 12 - 24 quilos de $P /$ ha e não mais 
de 46 quilos de $\mathrm{kg} / \mathrm{ha}$.

SANCHEZ e MATA (1972), na Venezuela, em solos de textura franco arenosa ainda não cultivado anteriormente, estudaram o efeito das formas de aplicação, fontes e doses de fósforo sobre o rendimento do amendoim (Araches hipogaea L.) e do feijào (Vigna sinensis Endl.), utilizando 3 fontes de fósforo (superfosfato simples, superfosfato triplo e fosforita), nas dosagens de 80,100 e $120 \mathrm{~kg} \mathrm{P}_{2} \mathrm{O}_{5} / \mathrm{ha}$, observaram que os rendimentos médios de ambas as culturas, foram influenciados pelas fontes, formas de aplicação e doses de fösforo; o uso de qualquer dos superfosfatos, simples e triplo, aumentou os rendimentos de ambas culturas de 1,5 a 2 vezes respectivamente, em comparação com os obtidos aplicando quantidades equivalentes de fósforo na forma de fosforita.

CAMPOS e DAMASCENO (1973), em experimento de adubação mineral NPK com Vigna sinensis (L.) Endl., conduzidos em solo de Penten coste, Ceará, sob condições de irrigação, observaram que o peso das sementes foi influenciado significativamente pela fertilização potássica e pela ação conjunta de $P$ e $K$.

PAIVA et alii (1973), estudando a adubação nitrogenada e fosfatada em feijão-de-corda, Vigna sinensis (L.) Savi., cultivar Pitiūba, em 2 locais do Ceará, utilizando 5 níveis de nitrogēnio $(0,30,60,90$ e $120 \mathrm{~kg} \mathrm{~N} / \mathrm{ha})$ e fósforo $\left(0,40,80,120\right.$ e $\left.160 \mathrm{~kg} \mathrm{P} \mathrm{O}_{5} / \mathrm{ha}\right)$, concluiram que ambos os nutrientes promoveram aulıentos significativos na produção, recomendando a utilização da fórmula 60-120-40 NPK.

GODFREY-SAM-AGGREY (1973), em Sierra Leone, em solos de planalto, obtiveram respostas favoráveis a adubação com NP e NPMg, sobre 
o aumento de produção de grãos de cowpea.

Estudos sobre o efeito do espaçamento e adubação NPK em Vegna sinensis (L.) Endl., conduzidos por PAIVA et alii (1974), em 8 diferentes localidades do Estado do Cearā, revelaram aumentos significativos de produção em cinco locais, tendo obtido a mais alta produção com a förmula 30-40-30 NPK.

CHESNEY (1974), em trabalho de pesquisa na Guiana, em um solo com 2 tipos de vegetação, savana e bosque, estudou o efeito do fós foro e potässio, sobre o rendimento, seus componentes e a nodulação de Vigna unguiculata Walp., observou que no local de vegetação de bosque, o potássio foi o fator limitante tanto para os rendimentos como para a nodução, sendo que em ambos os locais foram necessārios os dois elementos para obtenção de rendimentos ōtimos.

MALOTH e PRASAD (1976), em estudo de adubação NPK em solos da India, comparando o fósforo cedido por rochas fosfatadas e pelo superfosfato, relataram que Vigna sinensis (L.) Savi, respondeu bem ao fósforo, aumentando a produção de massa verde, sendo que o fosfato de rocha foi 50 a 55\% tão eficiente quanto o superfosfato. A aplicação de $50 \mathrm{~kg}$ de $\mathrm{P}_{2} \mathrm{O}_{5}$ como superfosfato ou fosfato de rocha, praticamente duplicou a absorção de fósforo pelo cowpea, quando comparado com o controle, sem fósforo. A aplicação de nitrogēnio aumentou a produção de massa verde.

BALASUBRAMANIAN e SINHA (1976), estudando o efeito da salinidade $(\mathrm{NaCl})$ sobre o crescimento, nodulação e acumulação de 
nitrogênio em Vigna sinensis (L.) e Vigna aureus (L.) cultivados em solução nutritiva, constataram que a salinidade retardou o crescimento das raizes, caules e folhas de ambas as culturas, sendo o cowpea menos sensivel. As taxas de crescimento relativo das vārias partes das plantas declinou inicialmente, sendo a seguir, por um periodo, mais altas do que aquelas do controle, sugerindo que as plantas tenderam a se adaptar as condições salinas.

ADAPETU e AKAPA (1977), em um estudo sobre crescimento de raízes e capacidade de absorção de nutrientes em 5 cultivares de cowpea na Nigéria, cultivadas em vasos com 2 tipos de solo, sendo um fértil e outro com deficiência de N, P e K, observaram que as plantas cultivadas em solo fërtil tiveram maior crescimento e que a insuficiēncia de potássio no solo, reduziu drasticamente a absorção de fósforo pelas raizes.

KASHIRAD et alii (1978), no Irã, estudaram os efeitos do fósforo e ferro no crescimento e conteüdosminerais de Vigna sinensis (L.), em 2 tipos de solo que receberam värias doses de $P \quad(0,50$, 100 e $200 \mathrm{ppm})$ e $\mathrm{Fe}(0,5,10$ e $20 \mathrm{ppm})$, sendo que o 10 solo tinha alto teor de sais solúveis, alto teor de Na trocável e baixos teores de $\mathrm{N}, \mathrm{Fe}, \mathrm{Zn}, \mathrm{Mn}$ e matéria orgânica, quando comparado com o 20 solo. Segundo os autores, a produção de matéria seca das plantas cultivadas no 10 solo, foi significativamente mais baixa do que aquelas cultivadas no 20 solo, com relação a todos os tratamentos. 0 maior crescimento das plantas foi obtido com a adição de 50 ou 100 ppm de fósforo em cada solo, não havendo necessidade de ferro no 20 solo, enquanto que foram 
necessārios a adição de 20 ppm de ferro ao 10 solo, para a obtenção de um ótimo crescimento. Os conteúdos de minerais nas partes aēreas das plantas em ambos os solos, foram diretamente afetadas com o aumento das doses de fósforo e ferro aplicados, tendo sido observadas interações sig nificativas entre os tratamentos fósforo e ferro para muitas das caracteristicas medidas.

DANTAS (1978), estudando nutrição mineral do feijão macassar (Vigna sinensis (L.) Endl.), utilizando duas variedades, Pitiūba e Dorminhoco, concluiu que os tratamentos que mais afetaram o desenvolvimento das plantas, foram em ordem decrescente: omissão de nitrogènio, cālcio, potássio, fósforo, ferro, boro e magnésio; em ambas as variedades, as exigenncias nutricionais para atingir o estādio reprodutivo são: $\mathrm{K}>\mathrm{N}>\mathrm{Ca}>\mathrm{Mg}>\mathrm{S}>\mathrm{P}$ para os macronutrientes $\mathrm{e} \mathrm{Fe}>$ $>\mathrm{B}>\mathrm{Mn}>\mathrm{Zn}>\mathrm{Cu}>\mathrm{Mo}$ para os micronutrientes.

STAMFORD (1978), estudando o efeito de estirpe de Rhizobium sp., de nitrogênio, fósforo e enxōfre na avaliação da fixação de $\mathrm{N}_{2}$, crescimento e absorção de nutrientes em Vigna unguiculata $\left(L_{.}\right)$Walp... observou que a aplicação de fósforo ao solo mostrou efeito positivo na absorção de nitrogènio, fósforo e enxōfre, enquanto que a adição deste ūltimo influiu apenas na absorção de enxōfre.

DANTAS et alii (1979), estudando as variações nos teores foliares de macro e micronutrientes em Vigna sinensis (L.) Endl., culti vado em solução nutritiva, constataram: a falta de um dado el emento provocou diminuição no seu teor; aumentos no teor de elementos não limitantes na ausência de outros no substrato como consequência do efeito 
de diluição e casos de interação explicado por influencia nos processos de absorção e transporte. Segundo os autores, a produção de matéria seca foi afetada na seguinte ordem decrescente: completo, $-S,-M g,-P$, $-\mathrm{K},-\mathrm{Ca},-\mathrm{N}$. 
3. MATERIAL E METODOS

0 experimento foi conduzido em casa de vegetação do Departamento de Quỉmica, na Escola Superior de Agricultura "Luiz de Queiroz", em Piracicaba (SP), sendo iniciado em 17-10-1979.

Utilizaram-se sementes de feijão (Vigna sinensis (L.)Endl.) 'Seridō', procedentes da UEPAE de Caicō - EMBRAPA, Campo Experimental de Cruzeta, Rio Grande do Norte.

Foram utilizados vasos cilindricos, de plástico com capacidade para 2 litros, contendo igual volume de quartzo moỉdo e lavado. Fo ram colocadas para germinar quatro sementes por vaso, deixando-se 2 plantas por vaso apōs o desbaste.

As plantas foram irrigadas com solução nutritiva completa, segundo SARRUGE (1975), diluida na razão de 1:2 com āgua destilada e renovada a cada 5 dias. Apōs 14 dias, quando as mudas apresentavam um aspecto uniforme com um número médio de 5 folhas por planta, fez-se. o desbaste. Antes de se iniciar os tratamentos, procedeu-se a uma lavagem do 
quartzo moido com ägua destilada, visando eliminar os nutrientes retidos pelo material.

0 delineamento experimental foi um fatorial $3^{4}$, estudandose o potássio, cálcio, magnésio e sōdio, nas concentraçōes abaixo, a partir de SARRUGE (1975).

$$
\begin{array}{ll}
\text { Potāssio: } & 0-117-234 \text { ppm } \\
\text { Cālcio: } & 0-100-200 \text { ppm } \\
\text { Magnésio: } & 0-24-48 \text { ppm } \\
\text { Sōdio: } & 0-92-184 \text { ppm }
\end{array}
$$

As concentraçōes māximas de cālcio, potássio, magnēsio e dos demais elementos, correspondem àquelas recomendadas por SARRUGE (1975), para a solução completa.

As plantas foram irrigadas duas vezes ao dia, a drenagem ocorria através de orifício no fundo de cada recipiente, ligados com tubos plásticos aos frascos coletores com capacidade de 1 litro; a renovação das soluções nutritivas foi feita a cada quatro dias.

Após 41 dias do plantio, iniciou-se a colheita dos primeiros tratamentos, prolongando-se atē os 51 dias.

0 material colnido foi lavado, separado em caules e foThas, secos em estufa com circulação forçada de ar a temperatura de 70$75^{\circ} \mathrm{C}$, até peso constante.

Apōs a determinaçào do peso do material seco, procedeu-se a moagem em moinho tipo Wiley malha 20 . As amostras foram analisadas 
quanto ao nitrogēnio, fósforo, potássio, cālcio, magnésio, enxōfre, boro, cobre, ferro, manganês e zinco, conforme metodologia citada em SARRUGE e HAAG (1974). O södio foi analisado por espectrofotometria de emissão. Os resultados analiticos foram analisados estatisticamente segundo PIMENTEL GOMES (1973). 
4. RESULTADOS

Na tabela 1 são apresentados os resultados de produção de matéria seca por planta nas folhas e caules.

As concentrações dos macro e micronutrientes determinados na matéria seca das folhas e caules encontram-se nas tabelas 2 à 7 e 8 a 13 respectivamente e os resumos das anälises da variāncia nas tabelas 14 à 18 . 
Tabela 1. Produção de matéria seca (g/planta) nas folhas e caules de Vigna sinensis (L.) EndT. em função dos nîveis de potāssio, cäicio, magnésio e södio

\begin{tabular}{|c|c|c|c|c|c|c|c|c|c|c|}
\hline a & & 00 & 01 & 02 & 10 & 11 & 12 & 20 & 21 & 22 \\
\hline \multirow[t]{2}{*}{00} & $F$ & 1,70 & 2,50 & 1,67 & 3,20 & 0,64 & 1,26 & 1,71 & 0,66 & 3,19 \\
\hline & C & 0,35 & 0,60 & 0,58 & 1,05 & 0,29 & 0,54 & 0,90 & 0,13 & 1,33 \\
\hline \multirow{2}{*}{01} & $\mathrm{~F}$ & 2,36 & 2,04 & 1,14 & 3,08 & 2,20 & 3,90 & 4,33 & 3,48 & 5,77 \\
\hline & C & 0,69 & 0,65 & 0,44 & 1,54 & 1,10 & 2,10 & 1,94 & 1,94 & 2,72 \\
\hline \multirow{2}{*}{02} & $\mathrm{~F}$ & 1,60 & 1,00 & 1,85 & 3,93 & 2,84 & 4,47 & 6,77 & 5,10 & 4,44 \\
\hline & C & 0,65 & 0,40 & 0,80 & 2,09 & 1,60 & 2,35 & 4,15 & 2,68 & 2,47 \\
\hline \multirow{2}{*}{10} & $\mathrm{~F}$ & 4,07 & 1,35 & 0,90 & 0,50 & 3,30 & 4,70 & 3,01 & 1,30 & 3,95 \\
\hline & C & 2,42 & 0,55 & 0,45 & 0,30 & 2,40 & 3,24 & 2,56 & 0,82 & 2,74 \\
\hline \multirow{2}{*}{11} & $\mathrm{~F}$ & 6,25 & 5,72 & 2,82 & 6,32 & 7,64 & 9,19 & 10,24 & 8,00 & 4,04 \\
\hline & C & 3,43 & 3,13 & 1,78 & 3,85 & 4,85 & 5,32 & 5,64 & 4,74 & 2,32 \\
\hline \multirow{2}{*}{12} & $\mathrm{~F}$ & 7,26 & 6,59 & 8,23 & 6,05 & 4,68 & 4,50 & 4,99 & 3,67 & 4,37 \\
\hline & C & 3,22 & 3,55 & 3,71 & 3,81 & 3,03 & 2,53 & 3,11 & 2,11 & 2,79 \\
\hline \multirow{2}{*}{20} & $\mathrm{~F}$ & 1,38 & 2,12 & 2,68 & 3,04 & 1,59 & 3,70 & 2,40 & 3,50 & 1,55 \\
\hline & C & 0,97 & 1,34 & 1,67 & 1,79 & 0,99 & 2,50 & 1,95 & 2,55 & 1,05 \\
\hline \multirow{2}{*}{21} & $\mathrm{~F}$ & 7,11 & 8,86 & 6,51 & 4,07 & 6,05 & 5,08 & 4,90 & 2,79 & 4,24 \\
\hline & C & 2,84 & 3,44 & 3,39 & 2,71 & 3,80 & 3,11 & 3,21 & 1,81 & 2,76 \\
\hline \multirow{2}{*}{22} & $\mathrm{~F}$ & 8,57 & 6,22 & 4,83 & 7,88 & 5,96 & 6,21 & 4,91 & 8,83 & 4,46 \\
\hline & C & 4,04 & 2,93 & 3,49 & 4,59 & 3,51 & 3,86 & 3,86 & 5,26 & 3,27 \\
\hline
\end{tabular}

$F=$ Folha $\quad C=$ Caule 
Tabela 2. Concentração de nitrogēnio (\%) na matéria seca das folthas e caules de Vigna sinensis (L.) Endl.

\begin{tabular}{|c|c|c|c|c|c|c|c|c|c|c|}
\hline $\mathrm{KCa}$ & $\mathrm{Na}$ & 00 & 01 & 02 & 10 & 11 & 12 & 20 & 21 & 22 \\
\hline \multirow{2}{*}{00} & $F$ & 4,21 & 5,91 & 6,03 & 6,59 & 4,68 & 3,78 & 5,95 & 5,46 & 5,89 \\
\hline & $c$ & 5,31 & 5,32 & 5,01 & 4,73 & 5,04 & 4,69 & 6,83 & 4,61 & 4,23 \\
\hline \multirow{2}{*}{01} & $F$ & 5,45 & 4,66 & 5,36 & 5,04 & 5,29 & 5,33 & 5,71 & 4,55 & 4,33 \\
\hline & C & 5,26 & 4,00 & 4,10 & 4,30 & 3,44 & 3,29 & 3,32 & 3,50 & 2,94 \\
\hline \multirow[b]{2}{*}{02} & $F$ & 5,14 & 5,00 & 5,22 & 5,56 & 3,91 & 4,61 & 3,99 & 5,64 & 4,93 \\
\hline & $c$ & 4,75 & 4,38 & 4,33 & 3,68 & 3,74 & 2,86 & 2,70 & 3,11 & 2,17 \\
\hline \multirow{2}{*}{10} & $F$ & 5,18 & 5,31 & 3,93 & 3,71 & 5,14 & 4,77 & 4,45 & 4,91 & 4,23 \\
\hline & C & 4,19 & 3,70 & 3,82 & 3,19 & 3,35 & 3,56 & 3,61 & 2,20 & 3,04 \\
\hline \multirow[b]{2}{*}{11} & $F$ & 4,24 & 3,91 & 4,09 & 4,72 & 4,77 & 4,62 & 4,40 & 4,80 & 4,49 \\
\hline & $c$ & 3,18 & 2,72 & 2,76 & 2,67 & 2,17 & ז'ו 2 & 2,09 & 2,69 & 2,52 \\
\hline \multirow[b]{2}{*}{12} & $F$ & 3,92 & 4,73 & 4,35 & 4,24 & 4,28 & 4,17 & 3,49 & 4,06 & 3,93 \\
\hline & $c$ & 2,69 & 2,58 & 1,97 & 1,51 & 2,30 & 2,25 & 1,99 & 2,45 & 1,95 \\
\hline \multirow{2}{*}{20} & $\mathrm{~F}$ & 4,56 & 4,20 & 4,61 & 4,05 & 4,07 & 4,52 & 4,10 & 4,54 & 4,65 \\
\hline & C & 3,74 & 3,26 & 3,28 & 2,80 & 2,95 & 2,86 & 2,53 & 3,05 & 2,66 \\
\hline \multirow{2}{*}{21} & $F$ & 3,18 & 4,33 & 4,47 & 4,20 & 4,65 & 3,84 & 4,70 & 4,27 & 4,77 \\
\hline & $c$ & 2,46 & 2,21 & 2,35 & 2,72 & 2,32 & 1,75 & 2,24 & $2,0.9$ & 2,16 \\
\hline \multirow[b]{2}{*}{22} & $F$ & 4,58 & 4,47 & 4,51 & 4,84 & 4,52 & 4,37 & 3,64 & 4,10 & 3,39 \\
\hline & $c$ & 2,60 & 2,39 & 2,03 & 2,04 & 1,99 & 1,62 & 2,11 & 1,33 & 2,10 \\
\hline
\end{tabular}

$F=$ Folha $\quad C=$ Caule 
Tabela 3. Concentração de fósforo (\%) na matéria seca das folhas e caules de Vigna sinensis (L.) Endl.

\begin{tabular}{|c|c|c|c|c|c|c|c|c|c|c|}
\hline $\mathrm{KCa}$ & $\mathrm{MgNa}$ & 00 & 01 & 02 & 10 & 11 & 12 & 20 & 21 & 22 \\
\hline \multirow[b]{2}{*}{00} & $F$ & 0,89 & 0,95 & 0,96 & 1,09 & 0,72 & 0,80 & 1,25 & 0,77 & 0,95 \\
\hline & $C$ & 0,46 & 0,47 & 0,58 & 0,25 & 0,40 & 0,41 & 0,65 & 0,46 & 0,42 \\
\hline \multirow{2}{*}{01} & $F$ & 0,76 & 0,90 & 0,59 & 0,70 & 0,62 & 0,83 & 0,79 & 0,91 & 0,74 \\
\hline & $C$ & 0,44 & 0,51 & 0,47 & 0,46 & 0,47 & 0,46 & 0,48 & 0,45 & 0,40 \\
\hline \multirow{2}{*}{02} & $F$ & 0,80 & 0,90 & 0,81 & 0,86 & 0,78 & 0,90 & 0,77 & 0,91 & 0,62 \\
\hline & $C$ & 0,52 & 0,67 & 0,53 & 0,48 & 0,53 & 0,41 & 0,43 & 0,43 & 0,41 \\
\hline \multirow{2}{*}{10} & $F$ & 0,59 & 0,63 & 0,83 & 0,45 & 0,74 & 0,78 & 0,59 & 0,70 & 0,61 \\
\hline & $C$ & 0,51 & 0,46 & 0,52 & 0,42 & 0,41 & 0,43 & 0,43 & 0,37 & 0,45 \\
\hline \multirow{2}{*}{11} & $F$ & 0,55 & 0,65 & 0,57 & 0,80 & 0,78 & 0,64 & 0,61 & 0,63 & 0,79 \\
\hline & $C$ & 0,39 & 0,37 & 0,40 & 0,46 & 0,31 & 0,38 & 0,41 & 0,44 & 0,40 \\
\hline \multirow{2}{*}{12} & $F$ & 0,66 & 0,63 & 0,58 & 0,58 & 0,57 & 0,44 & 0,50 & 0,49 & 0,40 \\
\hline & $C$ & 0,39 & 0,37 & 0,39 & 0,44 & 0,37 & 0,40 & 0,33 & 0,41 & 0,36 \\
\hline \multirow{2}{*}{20} & $\mathrm{~F}$ & 0,61 & 0,63 & 0,55 & 0,37 & 0,42 & 0,59 & 0,55 & 0,51 & 0,58 \\
\hline & $C$ & 0,42 & 0,46 & 0,42 & 0,43 & 0,43 & 0,46 & 0,44 & 0,46 & 0,49 \\
\hline \multirow{2}{*}{21} & $\mathrm{~F}$ & 0,65 & 0,66 & 0,72 & 0,55 & 0,67 & 0,54 & 0,36 & 0,59 & 0,48 \\
\hline & $C$ & 0,33 & 0,35 & 0,37 & 0,41 & 0,33 & 0,39 & 0,33 & 0,28 & 0,27 \\
\hline \multirow{2}{*}{22} & $F$ & 0,52 & 0,60 & 0,59 & 0,23 & 0,61 & 0,50 & 0,21 & 0,30 & 0,16 \\
\hline & $C$ & 0,43 & 0,37 & 0,31 & 0,36 & 0,30 & 0,29 & 0,26 & 0,20 & 0,27 \\
\hline
\end{tabular}


Tabela 4. Concentração de potāssio (\%) na matéria seca das folhas e caules de Vigna sinensis (L.) Endl.

\begin{tabular}{|c|c|c|c|c|c|c|c|c|c|c|}
\hline $\mathrm{KCa}$ & $\mathrm{MgNa}$ & 00 & 01 & 02 & 10 & 11 & 12 & 20 & 21 & 22 \\
\hline \multirow{2}{*}{00} & $F$ & 1,07 & 1,38 & 2,14 & 0,84 & 1,68 & 1,91 & 1,38 & 1,84 & 1,15 \\
\hline & $c$ & 0,38 & 0,31 & 0,77 & 0,46 & 0,46 & 0,38 & 1,07 & 0,77 & 0,46 \\
\hline \multirow[b]{2}{*}{01} & $F$ & 1,45 & 1,68 & 1,53 & 1,53 & 1,99 & 1,22 & 0,99 & 0,92 & 0,77 \\
\hline & $c$ & 1,30 & 0,77 & 0,77 & 0,69 & 0,92 & 0,54 & 0,77 & 0,61 & 0,46 \\
\hline \multirow[b]{2}{*}{02} & $\mathrm{~F}$ & 1,30 & 2,07 & 1,53 & 1,07 & 1,38 & 0,77 & 0,61 & 0,69 & 0,92 \\
\hline & $c$ & 0,77 & 1,53 & 1,07 & 0,61 & 0,77 & 0,54 & 0,46 & 0,38 & 0,46 \\
\hline \multirow[b]{2}{*}{10} & $\mathrm{~F}$ & 3,52 & 4,28 & 3,83 & 3,21 & 3,67 & 3,83 & 3,83 & 3,67 & 3,83 \\
\hline & $c$ & 1,76 & 2,45 & 2,45 & 2,30 & 2,45 & 1,38 & 2,22 & 3,06 & 1,68 \\
\hline \multirow[b]{2}{*}{11} & $\mathrm{~F}$ & 3,06 & 3,21 & 3,83 & 3,14 & 3,06 & 2,60 & 2,45 & 3,21 & 3,37 \\
\hline & $c$ & 1,99 & 1,68 & 1,53 & 1,99 & 1,68 & 1,99 & 1,68 & 2,30 & 1,84 \\
\hline \multirow[b]{2}{*}{12} & $\mathrm{~F}$ & 2,45 & 2,91 & 2,91 & 3,06 & 3,67 & 4,28 & 3,29 & 3,83 & 3,98 \\
\hline & $c$ & 2,30 & 2,22 & 1,84 & 2,14 & 2,30 & 1,91 & 2,14 & 2,91 & 2,14 \\
\hline \multirow[b]{2}{*}{20} & $\mathrm{~F}$ & 5,51 & 5,66 & 5,20 & 5,20 & 5,13 & 5,28 & 5,20 & 5,66 & 7,03 \\
\hline & $C$ & 4,74 & 4,44 & 3,67 & 3,75 & 4,28 & 3,44 & 4,74 & 4,13 & 6,66 \\
\hline \multirow[b]{2}{*}{21} & $\mathrm{~F}$ & 4,44 & 5,05 & 4,74 & 4,90 & 4,90 & 4,74 & 4,51 & 4,28 & 4,44 \\
\hline & $c$ & 3,67 & 3,29 & 2,91 & 3,98 & 3,83 & 2,91 & 4,44 & 3,52 & 3,60 \\
\hline \multirow[b]{2}{*}{22} & $F$ & 4,51 & 4,59 & 4,74 & 3,98 & 4,13 & 4,51 & 4,44 & 3,67 & 4,51 \\
\hline & $c$ & 4,28 & 4,13 & 3,06 & 3,67 & 3,67 & 3,21 & 2,75 & 2,45 & 2,14 \\
\hline
\end{tabular}

$F=$ Folha $\quad C=$ Caule 
Tabela 5. Concentração de cālcio (\%) na matēria seca das folhas e caules de Vigna sinensis (L.) Endl.

\begin{tabular}{|c|c|c|c|c|c|c|c|c|c|c|}
\hline $\mathrm{KCa}$ & & 00 & 01 & 02 & 10 & 11 & 12 & 20 & 21 & 22 \\
\hline \multirow[b]{2}{*}{00} & $F$ & 0,69 & 0,65 & 1,09 & 0,57 & 1,26 & 1,21 & 0,98 & 1,09 & 0,59 \\
\hline & $c$ & 0,51 & 0,18 & 0,34 & 0,12 & 0,33 & 0,21 & 0,30 & 0,20 & 0,12 \\
\hline \multirow{2}{*}{01} & $F$ & 2,54 & 2,59 & 1,81 & 2,53 & 2,56 & 2,60 & 2,47 & 2,41 & 2,23 \\
\hline & $C$ & 1,85 & 1,19 & 1,12 & 0,74 & 0,68 & 0,59 & 1,11 & 0,64 & 0,51 \\
\hline \multirow[b]{2}{*}{02} & $F$ & 3,49 & 3,37 & 2,92 & 3,24 & 3,31 & 3,84 & 3,32 & 3,84 & 2,97 \\
\hline & $c$ & 1,88 & 1,81 & 1,63 & 1,19 & 1,13 & 1,00 & 0,96 & 0,91 & 0,61 \\
\hline \multirow{2}{*}{10} & $F$ & 1,24 & 0,93 & 1,16 & 1,02 & 0,88 & 0,51 & 0,87 & 1,00 & 0,85 \\
\hline & $C$ & 0,32 & 0,35 & 0,36 & 0,32 & 0,20 & 0,12 & 0,16 & 0,19 & 0,13 \\
\hline \multirow{2}{*}{11} & $F$ & 1,94 & 2,20 & 1,92 & 2,36 & 2,67 & 2,51 & 2,70 & 2,71 & 1,80 \\
\hline & $C$ & 0,88 & 0,90 & 0,69 & 0,84 & 0,53 & 0,64 & 0,75 & 0,68 & 0,57 \\
\hline \multirow{2}{*}{12} & $F$ & 3,08 & 3,67 & 3,01 & 3,46 & 3,01 & 2,71 & 3,09 & 3,10 & 3,02 \\
\hline & $C$ & 1,81 & 1,30 & 1,24 & 1,11 & 0,98 & 0,93 & 0,84 & 1,04 & 0,78 \\
\hline \multirow{2}{*}{20} & $F$ & 1,10 & 1,04 & 1,15 & 0,68 & 0,95 & 0,88 & 0,92 & 0,86 & 0,76 \\
\hline & $C$ & 0,31 & 0,28 & 0,22 & 0,18 & 0,22 & 0,20 & 0,22 & 0,17 & 0,24 \\
\hline \multirow[b]{2}{*}{21} & $F$ & 1,67 & 1,56 & 1,75 & 1,65 & 2,30 & 1,56 & 2,23 & 2,21 & 1,65 \\
\hline & $c$ & 1,18 & 1,03 & 0,77 & 0,7 & 0,7 & 0,53 & 0,65 & 0,56 & 0,52 \\
\hline \multirow{2}{*}{22} & $\mathrm{~F}$ & 1,09 & 2,17 & 2,48 & 3,24 & 2,86 & 2,68 & 2,85 & 2,98 & 2,75 \\
\hline & $C$ & 1,53 & 1,26 & 0,96 & 1,09 & 0,94 & 0,79 & 0,62 & 0,72 & 0,65 \\
\hline
\end{tabular}


Tabela 6. Concentração de magnésio (\%) na matēria seca das folhas e caules de Vigna sinensis (L.) Endl.

\begin{tabular}{|c|c|c|c|c|c|c|c|c|c|c|}
\hline $\mathrm{KCa}$ & $\mathrm{MgNa}$ & 00 & 01 & 02 & 10 & 11 & 12 & 20 & 21 & 22 \\
\hline \multirow{2}{*}{00} & $\mathrm{~F}$ & 0,18 & 0,23 & 0,31 & 0,74 & 0,60 & 0,66 & 1,05 & 0,86 & 0,92 \\
\hline & $c$ & 0,32 & 0,15 & 0,20 & 0,82 & 0,40 & 0,34 & 1,09 & 0,66 & 0,66 \\
\hline \multirow{2}{*}{01} & $F$ & 0,17 & 0,24 & 0,19 & 0,56 & 0,61 & 0,68 & 0,83 & 0,83 & 0,96 \\
\hline & c & 0,29 & 0,11 & 0,17 & 0,54 & 0,50 & 0,48 & 0,92 & 0,63 & 0,71 \\
\hline \multirow{2}{*}{02} & $F$ & 0,16 & 0,29 & 0,18 & 0,46 & 0,49 & 0,70 & 0,74 & 0,87 & 0,66 \\
\hline & C & 0,25 & 0,28 & 0,19 & 0,51 & 0,46 & 0,52 & 0,64 & 0,67 & 0,53 \\
\hline \multirow{2}{*}{10} & $F$ & 0,22 & 0,17 & 0,25 & 0,54 & 0,48 & 0,50 & 0,63 & 0,72 & 0,66 \\
\hline & $c$ & 0,23 & 0,14 & 0,12 & 0,37 & 0,41 & 0,34 & 0,51 & 0,58 & 0,46 \\
\hline \multirow{2}{*}{11} & $F$ & 0,11 & 0,14 & 0,19 & 0,37 & 0,50 & 0,49 & 0,75 & 0,81 & 0,64 \\
\hline & $C$ & 0,11 & 0,10 & 0,12 & 0,46 & 0,45 & 0,51 & 0,87 & 0,73 & 0,57 \\
\hline \multirow{2}{*}{12} & $F$ & 0,10 & 0,14 & 0,11 & 0,40 & 0,41 & 0,37 & 0,57 & 0,60 & 0,55 \\
\hline & $C$ & 0,13 & 0,11 & 0,10 & 0,46 & 0,36 & 0,34 & 0,54 & 0,67 & 0,43 \\
\hline \multirow{2}{*}{20} & $F$ & 0,25 & 0,25 & 0,21 & 0,37 & 0,47 & 0,41 & 0,56 & 0,63 & 0,53 \\
\hline & $c$ & 0,18 & 0,19 & 0,15 & 0,43 & 0,30 & 0,32 & 0,45 & 0,53 & 0,40 \\
\hline \multirow{2}{*}{21} & $F$ & 0,09 & 0,08 & 0,10 & 0,35 & 0,41 & 0,34 & 0,58 & 0,56 & 0,55 \\
\hline & C & 0,10 & 0,09 & 0,09 & 0,43 & 0,45 & 0,32 & 0,67 & 0,50 & 0,47 \\
\hline \multirow{2}{*}{22} & $F$ & 0,10 & 0,10 & 0,11 & 0,23 & 0,37 & 0,39 & 0,54 & 0,52 & 0,44 \\
\hline & C & 0,13 & 0,11 & 0,09 & 0,34 & 0,46 & 0,29 & 0,49 & 0,48 & 0,37 \\
\hline
\end{tabular}

$F=$ Folha $\quad C=$ Caule 
Tabela 7. Concentração de enxōfre (\%) na matēria seca das folhas e caules de Vigna sinensis (L.) End?.

\begin{tabular}{|c|c|c|c|c|c|c|c|c|c|c|}
\hline & la & 00 & 01 & 02 & 10 & 11 & 12 & 20 & 21 & 22 \\
\hline & $F$ & 0,25 & 0,24 & 0,33 & 0,53 & 0,23 & 0,35 & 0,44 & 0,34 & 0,38 \\
\hline 00 & $C$ & 0,78 & 0,63 & 0,83 & 0,64 & 0,65 & 0,75 & 0,70 & 0,38 & 0,60 \\
\hline & $F$ & 0,40 & 0,23 & 0,18 & 0,32 & 0,20 & 0,30 & 0,30 & 0,23 & 0,34 \\
\hline 01 & C & 0,65 & 0,70 & 0,68 & 0,47 & 0,46 & 0,48 & 0,62 & 0,48 & 0,66 \\
\hline & $F$ & 0,26 & 0,20 & 0,17 & 0,22 & 0,19 & 0,23 & 0,19 & 0,23 & 0,17 \\
\hline 02 & $C$ & 0,67 & 0,73 & 0,52 & 0,60 & 0,53 & 0,53 & 0,38 & 0,41 & 0,44 \\
\hline & $F$ & 0,51 & 0,54 & 0,30 & 0,36 & 0,37 & 0,36 & 0,30 & 0,32 & 0,33 \\
\hline 10 & $C$ & 0,50 & 0,75 & 0,48 & 0,55 & 0,49 & 0,41 & 0,44 & 0,53 & 0,41 \\
\hline & $F$ & 0,38 & 0,39 & 0,30 & 0,39 & 0,35 & 0,28 & 0,44 & 0,34 & 0,37 \\
\hline 11 & $C$ & 0,44 & 0,55 & 0,44 & 0,44 & 0,45 & 0,39 & 0,58 & 0,53 & 0,52 \\
\hline & $F$ & 0,35 & 0,30 & 0,27 & 0,22 & 0,22 & 0,37 & 0,22 & 0,16 & 0,26 \\
\hline 12 & $C$ & 0,53 & 0,46 & 0,42 & 0,46 & 0,44 & 0,48 & 0,58 & 0,48 & 0,42 \\
\hline & $F$ & 0,36 & 0,34 & 0,34 & 0,40 & 0,39 & 0,34 & 0,41 & 0,42 & 0,30 \\
\hline 20 & $C$ & 0,43 & 0,44 & 0,39 & 0,46 & 0,44 & 0,39 & 0,43 & 0,48 & 0,47 \\
\hline & $F$ & 0,32 & 0,41 & 0,29 & 0,36 & 0,32 & 0,30 & 0,39 & 0,24 & 0,25 \\
\hline 21 & $c$ & 0,53 & 0,46 & 0,51 & 0,53 & 0,44 & 0,48 & 0,43 & 0,35 & 0,33 \\
\hline & $F$ & 0,30 & 0,25 & 0,28 & 0,30 & 0,24 & 0,30 & 0,33 & 0,18 & 0,50 \\
\hline 22 & C & 0,56 & 0,39 & 0,40 & 0,41 & 0,36 & 0,36 & 0,37 & 0,35 & 0,33 \\
\hline
\end{tabular}

$F=$ Folha $\quad C=$ Caule 
Tabela 8. Concentração de boro (ppm) na matéria seca das folhas e caules de Vigna sinensis (L.) Endr.

\begin{tabular}{|c|c|c|c|c|c|c|c|c|c|c|}
\hline $\mathrm{KCa}$ & $\mathrm{MgNa}$ & 00 & 01 & 02 & 10 & 11 & 12 & 20 & 21 & 22 \\
\hline \multirow{2}{*}{00} & $F$ & 19 & 80 & 159 & 137 & 150 & 120 & 196 & 39 & 96 \\
\hline & $C$ & 18 & 11 & 104 & 64 & 40 & 86 & 70 & 69 & 56 \\
\hline \multirow{2}{*}{01} & $\mathrm{~F}$ & 172 & 127 & 212 & 145 & 155 & 143 & 129 & 103 & 121 \\
\hline & $c$ & 61 & 99 & 149 & 30 & 35 & 43 & 42 & 29 & 52 \\
\hline \multirow{2}{*}{02} & $\mathrm{~F}$ & 131 & 194 & 171 & 150 & 131 & 146 & 116 & 127 & 102 \\
\hline & $c$ & 53 & 55 & 65 & 53 & 38 & 44 & 33 & 35 & 26 \\
\hline \multirow{2}{*}{10} & $F$ & 173 & 153 & 169 & 131 & 191 & 135 & 146 & 152 & 109 \\
\hline & $c$ & 57 & 155 & 94 & 24 & 21 & 24 & 35 & 72 & 29 \\
\hline \multirow{2}{*}{11} & $\mathrm{~F}$ & 143 & 145 & 113 & 159 & 165 & 132 & 148 & 120 & 127 \\
\hline & $C$ & 24 & 52 & 67 & 24 & 34 & 36 & 28 & 24 & 25 \\
\hline \multirow{2}{*}{12} & $F$ & 118 & 138 & 96 & 155 & 118 & 127 & 141 & 125 & 110 \\
\hline & $c$ & 32 & 99 & 33 & 25 & 28 & 106 & 27 & 75 & 29 \\
\hline \multirow{2}{*}{20} & $F$ & 160 & 147 & 125 & 140 & 122 & 118 & 166 & 160 & 93 \\
\hline & $c$ & 55 & 55 & 59 & 49 & 35 & 50 & 45 & 46 & 40 \\
\hline \multirow[t]{2}{*}{21} & $F$ & 118 & 130 & 118 & 116 & 157 & 103 & 162 & 114 & 122 \\
\hline & $c$ & 34 & 44 & 58 & 39 & 32 & 59 & 36 & 29 & 37 \\
\hline \multirow[t]{2}{*}{22} & $\mathrm{~F}$ & 161 & 102 & 125 & 138 & 132 & 126 & 132 & 99 & 118 \\
\hline & $c$ & 32 & 62 & 103 & 30 & 48 & 25 & 28 & 73 & 26 \\
\hline
\end{tabular}


Tabela 9. Concentração de cobre (ppm) na matéria seca das folhas e caules de Vigna sinensis (L.) Endr.

\begin{tabular}{|c|c|c|c|c|c|c|c|c|c|c|}
\hline $\mathrm{KCa}$ & $\mathrm{MgNa}$ & 00 & 01 & 02 & 10 & 11 & 12 & 20 & 21 & 22 \\
\hline \multirow{2}{*}{00} & $\mathrm{~F}$ & 6 & 7 & 8 & 7 & 5 & 6 & 7 & 8 & 5 \\
\hline & $C$ & 8 & 5 & 9 & 7 & 5 & 5 & 5 & 7 & 6 \\
\hline \multirow{2}{*}{01} & $F$ & 10 & 8 & 7 & 8 & 7 & 6 & 9 & 5 & 8 \\
\hline & $C$ & 10 & 6 & 7 & 6 & 7 & 8 & 8 & 5 & 6 \\
\hline \multirow{2}{*}{02} & $\mathrm{~F}$ & 5 & 9 & 10 & 7 & 6 & 8 & 5 & 7 & 9 \\
\hline & $C$ & 6 & 6 & 8 & 5 & 6 & 5 & 4 & 6 & 24 \\
\hline \multirow{2}{*}{10} & $F$ & 7 & 7 & 5 & 6 & 10 & 6 & 7 & 6 & 6 \\
\hline & $C$ & 5 & 25 & 5 & 5 & 5 & 5 & 4 & 4 & 5 \\
\hline \multirow{2}{*}{11} & $\mathrm{~F}$ & 7 & 7 & 6 & 7 & 8 & 7 & 8 & 8 & 8 \\
\hline & $C$ & 4 & 3 & 4 & 4 & 5 & 5 & 6 & 6 & 5 \\
\hline \multirow{2}{*}{12} & $F$ & 7 & 6 & 7 & 5 & 6 & 5 & 5 & 5 & 4 \\
\hline & $C$ & 5 & 3 & 4 & 3 & 3 & 2 & 3 & 2 & 2 \\
\hline \multirow{2}{*}{20} & $\mathrm{~F}$ & 7 & 6 & 5 & 4 & 5 & 6 & 6 & 7 & 4 \\
\hline & $C$ & 3 & 3 & 4 & 3 & 3 & 4 & 6 & 5 & 2 \\
\hline \multirow[t]{2}{*}{21} & $\mathrm{~F}$ & 5 & 7 & 8 & 6 & 6 & 4 & 6 & 6 & 8 \\
\hline & $C$ & 3 & 4 & 2 & 2 & 2 & 2 & 3 & 2 & 3 \\
\hline \multirow[t]{2}{*}{22} & $F$ & 8 & 7 & 7 & 4 & 5 & 6 & 5 & 6 & 5 \\
\hline & $C$ & 4 & 2 & 3 & 2 & 2 & 3 & 2 & 2 & 2 \\
\hline
\end{tabular}

$F=$ Folha $\quad C=$ Caule 
Tabela 10. Concentração de ferro (ppm) na matēria seca das folhas e caules de Vigna sinensis (L.) Endr.

\begin{tabular}{|c|c|c|c|c|c|c|c|c|c|c|}
\hline $\mathrm{KCa}$ & $\mathrm{MgNa}$ & 00 & 01 & 02 & 10 & 11 & 12 & 20 & 21 & 22 \\
\hline \multirow{2}{*}{00} & $F$ & 463 & 548 & 412 & 576 & 270 & 289 & 201 & 147 & 273 \\
\hline & $C$ & 142 & 159 & 175 & 92 & 185 & 163 & 170 & 177 & 108 \\
\hline \multirow{2}{*}{01} & $F$ & 143 & 371 & 225 & 196 & 210 & 136 & 208 & 166 & 268 \\
\hline & C & 84 & 134 & 273 & 111 & 157 & 130 & 102 & 104 & 169 \\
\hline \multirow{2}{*}{02} & $F$ & 136 & 238 & 240 & 148 & 138 & 226 & 148 & 217 & 96 \\
\hline & $C$ & 153 & 187 & 191 & 88 & 42 & 93 & 46 & 70 & 45 \\
\hline \multirow{2}{*}{10} & $F$ & 142 & 249 & 297 & 319 & 262 & 314 & 206 & 359 & 572 \\
\hline & $C$ & 54 & 85 & 80 & 88 & 57 & 50 & 39 & 61 & 50 \\
\hline \multirow{2}{*}{11} & $F$ & 325 & 450 & 328 & 379 & 308 & 251 & 574 & 153 & 304 \\
\hline & $C$ & 59 & 75 & 69 & 68 & 95 & 82 & 101 & 93 & 59 \\
\hline \multirow{2}{*}{12} & $F$ & 11 & 95 & 63 & 145 & 93 & 100 & 132 & 130 & 114 \\
\hline & C & 64 & 83 & 62 & 49 & 79 & 65 & 187 & 63 & 94 \\
\hline \multirow{2}{*}{20} & $\mathrm{~F}$ & 266 & 227 & 155 & 150 & 165 & 228 & 212 & 193 & 307 \\
\hline & $C$ & 156 & 71 & 118 & 53 & 68 & 49 & 76 & 52 & 55 \\
\hline \multirow{2}{*}{21} & $F$ & 270 & 71 & 61 & 119 & 100 & 110 & 99 & 154 & 114 \\
\hline & C & 70 & 58 & 59 & 77 & 70 & 53 & 108 & 47 & 55 \\
\hline \multirow{2}{*}{22} & $F$ & 88 & 96 & 86 & 64 & 53 & 58 & 44 & 64 & 18 \\
\hline & $C$ & 76 & 70 & 77 & 70 & 47 & $53^{\circ}$ & 51 & 138 & 49 \\
\hline
\end{tabular}

$F=$ Folha $c=$ Caule 
Tabela 11. Concentração de manganēs (ppm) na matēria seca das folhas e caules de Vigna sinensis (L.) Endl.

\begin{tabular}{|c|c|c|c|c|c|c|c|c|c|c|}
\hline$K C_{a}$ & $\mathrm{MgNa}$ & 00 & 01 & 02 & 10 & 11 & 12 & 20 & 21 & 22 \\
\hline \multirow{2}{*}{00} & $F$ & 264 & 321 & 312 & 305 & 172 & 223 & 306 & 215 & 240 \\
\hline & C & 192 & 129 & 92 & 104 & 32 & 48 & 89 & 54 & 57 \\
\hline \multirow{2}{*}{01} & $F$ & 297 & 270 & 263 & 285 & 350 & 238 & 248 & 182 & 201 \\
\hline & C & 145 & 40 & 59 & 55 & 35 & 23 & 59 & 30 & 32 \\
\hline \multirow{2}{*}{02} & $F$ & 200 & 260 & 289 & 229 & 188 & 247 & 170 & 201 & 153 \\
\hline & C & 46 & 33 & 74 & 53 & 32 & 38 & 25 & 26 & 19 \\
\hline \multirow{2}{*}{10} & $F$ & 226 & 218 & 151 & 90 & 246 & 182 & 190 & 149 & 236 \\
\hline & C & 74 & 110 & 99 & 20 & 47 & 55 & 30 & 53 & 32 \\
\hline \multirow{2}{*}{11} & $F$ & 161 & 202 & 181 & 185 & 203 & 188 & 213 & 231 & 168 \\
\hline & $c$ & 18 & 27 & 23 & 28 & 22 & 28 & 25 & 34 & 23 \\
\hline \multirow{2}{*}{12} & $F$ & 169 & 180 & 173 & 131 & 119 & 120 & 116 & 132 & 97 \\
\hline & $c$ & 38 & 24 & 26 & 12 & 13 & 14 & 14 & 16 & 11 \\
\hline \multirow{2}{*}{20} & $F$ & 207 & 224 & 227 & 105 & 183 & 195 & 244 & 255 & 176 \\
\hline & $c$ & 55 & 43 & 62 & 50 & 34 & 41 & 44 & 49 & 33 \\
\hline \multirow{2}{*}{21} & $F$ & 158 & 161 & 188 & 158 & 175 & 136 & 190 & 130 & 168 \\
\hline & $c$ & 58 & 44 & 42 & 28 & 21 & 15 & 27 & 26 & 20 \\
\hline \multirow{2}{*}{22} & $F$ & 181 & 183 & 186 & 107 & 122 & 143 & ור & 93 & 60 \\
\hline & C & 36 & 39 & 25 & 21 & 15 & 18 & 6 & 11 & 8 \\
\hline
\end{tabular}

$F=$ Folha $\quad C=$ Caule 
Tabela 12. Concentração de zinco (ppm) na matéria seca das folhas e caules de Vigna sinensis (L.) Endl.

\begin{tabular}{|c|c|c|c|c|c|c|c|c|c|c|}
\hline $\mathrm{KCa}$ & $\mathrm{MgNa}$ & 00 & 01 & 02 & 10 & 11 & 12 & 20 & 21 & 22 \\
\hline \multirow{2}{*}{00} & $F$ & 55 & 100 & 72 & 133 & 61 & 83 & 73 & 83 & 74 \\
\hline & C & 53 & 160 & 76 & 146 & 33 & 40 & 39 & 66 & 70 \\
\hline \multirow{2}{*}{01} & $F$ & 110 & 55 & 62 & 66 & 120 & 50 & 123 & 37 & 40 \\
\hline & $C$ & 93 & 46 & 110 & 53 & 129 & 37 & 133 & 17 & 29 \\
\hline \multirow{2}{*}{02} & $F$ & 39 & 59 & 88 & 45 & 54 & 71 & 38 & 54 & 47 \\
\hline & $C$ & 41 & 76 & 150 & 39 & 71 & 55 & 19 & 36 & 35 \\
\hline \multirow[t]{2}{*}{10} & $F$ & 92 & 57 & 59 & 45 & 86 & 62 & 55 & 62 & 76 \\
\hline & $C$ & 85 & 101 & 95 & 22 & 74 & 40 & 32 & 71 & 66 \\
\hline \multirow[t]{2}{*}{11} & $F$ & 66 & 59 & 62 & 52 & 55 & 40 & 48 & 53 & 42 \\
\hline & $C$ & 49 & 28 & 37 & 20 & 17 & 18 & 21 & 26 & 14 \\
\hline \multirow[t]{2}{*}{12} & $F$ & 42 & 53 & 49 & 47 & 39 & 36 & 35 & 45 & 42 \\
\hline & $c$ & 25 & 18 & 35 & 18 & 16 & 17 & 11 & 20 & 21 \\
\hline \multirow[t]{2}{*}{20} & $F$ & 45 & 51 & 50 & 50 & 41 & 110 & 92 & 60 & 48 \\
\hline & $C$ & 40 & 45 & 50 & 53 & 27 & 100 & 82 & 55 & 35 \\
\hline \multirow{2}{*}{21} & $F$ & 40 & 36 & 58 & 78 & 63 & 40 & 51 & 64 & 66 \\
\hline & $C$ & 32 & 28 & 34 & 46 & 28 & 19 & 26 & 36 & 54 \\
\hline \multirow{2}{*}{22} & $F$ & 56 & 63 & 49 & 35 & 42 & 67 & 31 & 27 & 18 \\
\hline & C & 67 & 133 & 46 & 31 & 21 & 32 & 13 & 14 & 12 \\
\hline
\end{tabular}

$F=$ Folha $C=$ Caule 
Tabela 13. Concentração de sōdio (ppm) na matēria seca das foihas e caules de Vigna sinensis (L.) Endl.

\begin{tabular}{|c|c|c|c|c|c|c|c|c|c|c|}
\hline $\mathrm{KCa}$ & $\mathrm{gaa}$ & 00 & 01 & 02 & 10 & 11 & 12 & 20 & 21 & 22 \\
\hline \multirow{2}{*}{00} & $F$ & 255 & 1404 & 1531 & 255 & 510 & 1531 & 255 & 590 & 2552 \\
\hline & C & 510 & 8.677 & 16.320 & 255 & 4.594 & 12.240 & 510 & 8.677 & 10.718 \\
\hline \multirow{2}{*}{01} & $F$ & 400 & 500 & 600 & 255 & 255 & 1276 & 128 & 128 & 255 \\
\hline & $c$ & 255 & 7.146 & 8.932 & 255 & 4.338 & 6.380 & 255 & 4.211 & 7.911 \\
\hline \multirow{2}{*}{02} & $F$ & 350 & 600 & 900 & 255 & 255 & 510 & 128 & 255 & 766 \\
\hline & $c$ & 255 & 3.818 & 7.146 & 255 & 4.594 & 7.401 & 766 & 4.083 & 6.890 \\
\hline \multirow{2}{*}{10} & $F$ & 255 & 893 & 2042 & 300 & 400 & 1300 & 255 & 255 & 510 \\
\hline & C & 638 & 8.677 & 14.790 & 510 & 4.338 & 9.953 & 383 & 6.125 & 7.911 \\
\hline \multirow{2}{*}{11} & $F$ & 255 & 255 & 510 & 383 & 510 & 2297 & 383 & 766 & 1021 \\
\hline & C & 766 & 8.166 & 12.750 & 510 & 3.573 & 12.240 & 510 & 6.125 & 15.810 \\
\hline \multirow{2}{*}{12} & $F$ & 255 & 510 & 1786 & 255 & 255 & 893 & 300 & 400 & 600 \\
\hline & $C$ & 638 & 7.146 & 12.240 & 1.021 & 5.104 & 14.280 & 383 & 6.625 & 8.294 \\
\hline \multirow{2}{*}{20} & $F$ & 383 & 510 & 510 & 255 & 383 & 510 & 200 & 600 & 400 \\
\hline & C & 766 & 5.870 & 8.932 & 766 & 8.677 & 6.635 & 383 & 4.338 & 7.528 \\
\hline \multirow{2}{*}{21} & $F$ & 255 & 638 & 1531 & 400 & 500 & 800 & 255 & 510 & 1148 \\
\hline & $c$ & 766 & 8.549 & 11.220 & 510 & 5.870 & 9.953 & 510 & 4.083 & 7.656 \\
\hline \multirow{2}{*}{22} & $F$ & 255 & 510 & 1786 & 255 & 510 & 1148 & 600 & 500 & 700 \\
\hline & C & 510 & 5.870 & 12.750 & 638 & 5.359 & 9.953 & 255 & 5.359 & 7.146 \\
\hline
\end{tabular}

$F=$ Folha $\quad C=$ Caule 
Tabela 14. Resumo das anālises de variāncia da produção de matéria seca ( $g / p l a n t a)$ das folhas e caules de Vigna sinensis (L.) Endl.

\begin{tabular}{|c|c|c|c|}
\hline \multirow[b]{2}{*}{ Causa de variação } & \multirow[b]{2}{*}{ GL } & \multicolumn{2}{|c|}{ QM } \\
\hline & & $\begin{array}{c}\text { Matéria seca } \\
\text { das f lhas }\end{array}$ & $\begin{array}{c}\text { Matéria seca } \\
\text { do caule }\end{array}$ \\
\hline K & 2 & $37,1162 * \star$ & $21,4178 \star \star$ \\
\hline $\mathrm{Ca}$ & 2 & $74,3828 \star \star$ & $21,6344 * \star$ \\
\hline $\mathrm{Mg}$ & 2 & 0,9947 & $4,0445^{\star}$ \\
\hline $\mathrm{Na}$ & 2 & 1,9356 & 0,4820 \\
\hline $\mathrm{K} \times \mathrm{Ca}$ & 4 & 6,6412 & 2,1734 \\
\hline $\mathrm{K} \times \mathrm{Mg}$ & 4 & 6,6599 & 1,1392 \\
\hline $\mathrm{K} \times \mathrm{Na}$ & 4 & 1,5367 & 0,2490 \\
\hline $\mathrm{Ca} \times \mathrm{Mg}$ & 4 & 0,1672 & 0,2030 \\
\hline $\mathrm{Ca} \times \mathrm{Na}$ & 4 & 1,3414 & 0,4180 \\
\hline $\mathrm{Mg} \times \mathrm{Na}$ & 4 & 2,3036 & 0,7009 \\
\hline $\mathrm{K} \times \mathrm{Ca} \times \mathrm{Mg}$ & 8 & $6,9938 *$ & 1,3140 \\
\hline $\mathrm{K} \times \mathrm{Ca} \times \mathrm{Na}$ & 8 & 1,2871 & 0,3439 \\
\hline $\mathrm{Ca} \times \mathrm{Mg} \times \mathrm{Na}$ & 8 & 1,7537 & 0,3576 \\
\hline $\mathrm{K} \times \mathrm{Mg} \times \mathrm{Na}$ & 8 & 1,6727 & 0,5862 \\
\hline Resĩduo & 16 & 2,5951 & 0,9038 \\
\hline Total & 80 & & \\
\hline C.V.\% & & 38,39 & 40,22 \\
\hline
\end{tabular}

* Quadrados médios correspondentes a valores de F significativos a $5 \%$ de probabilidade.

** Quadrados mëdios correspondentes a valores de F significativos a $1 \%$ de probabilidade. 


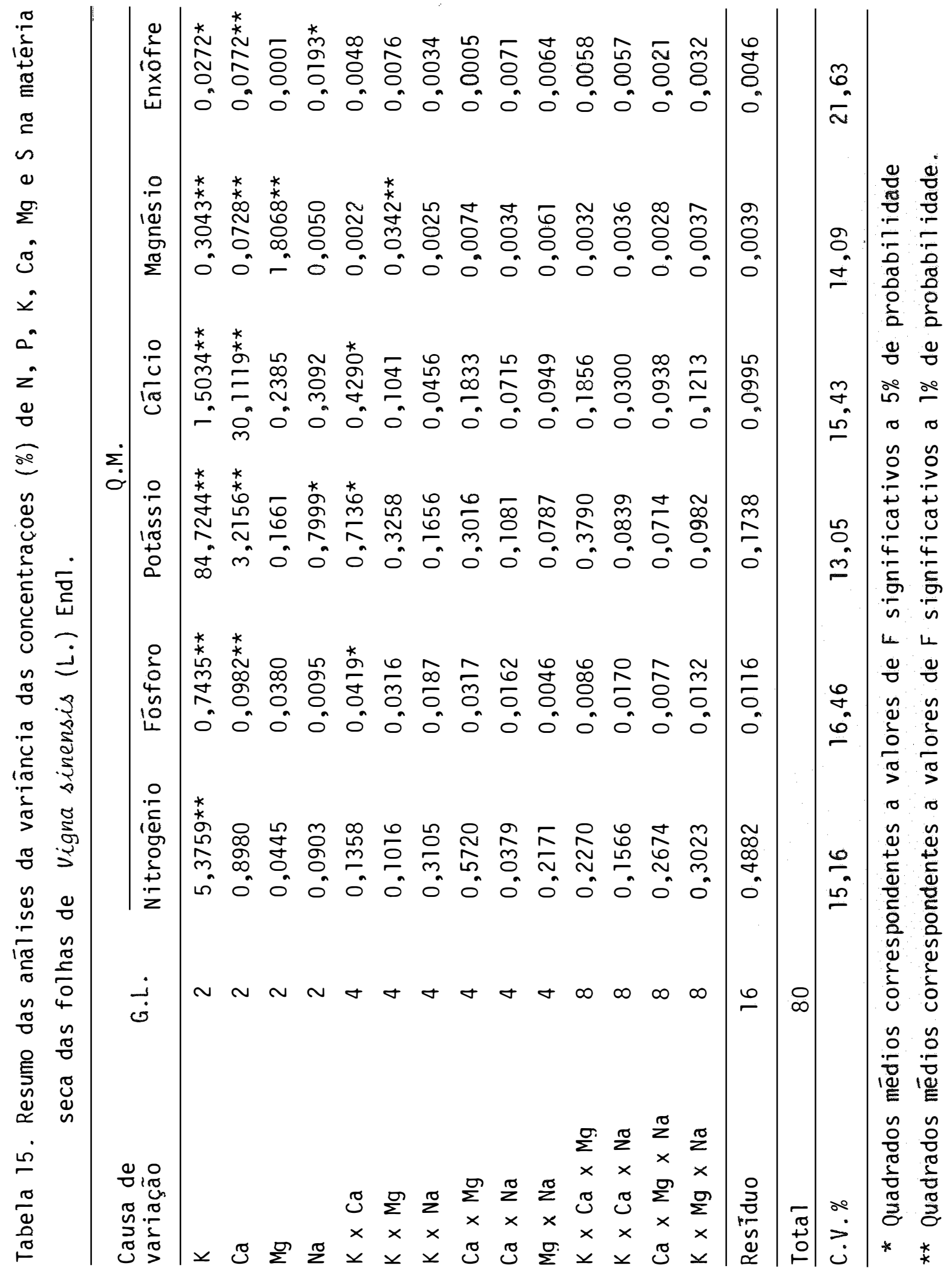




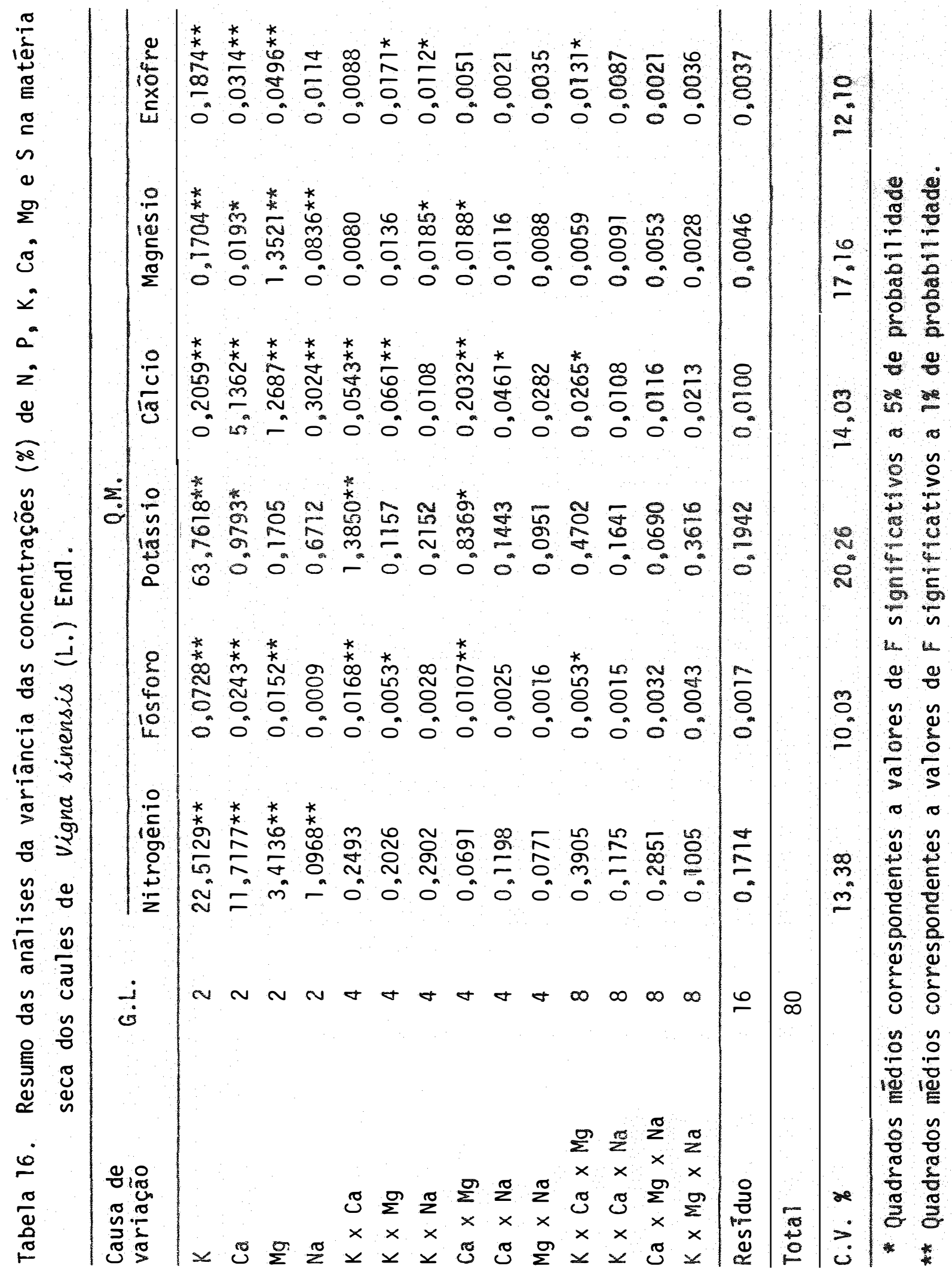




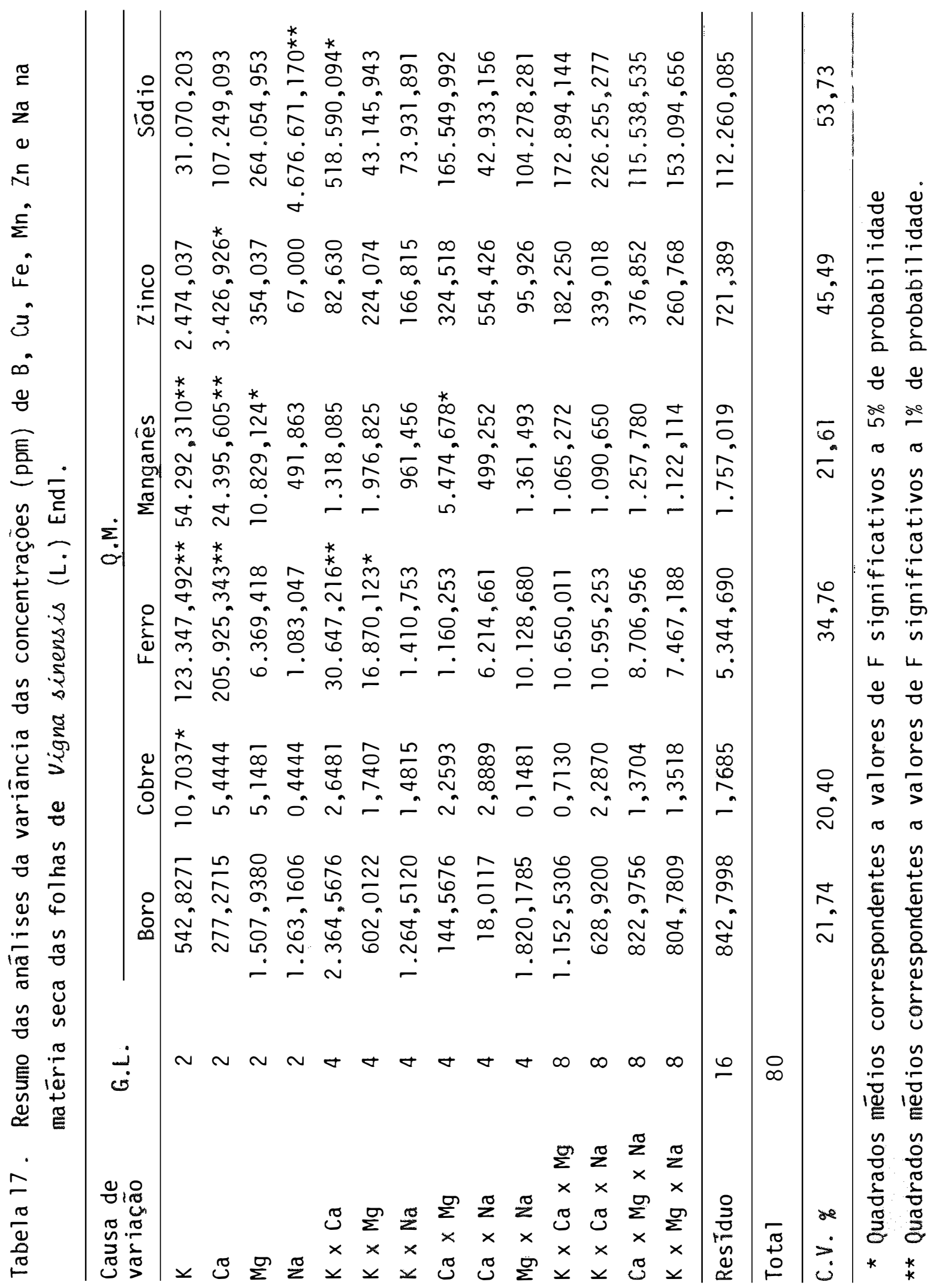




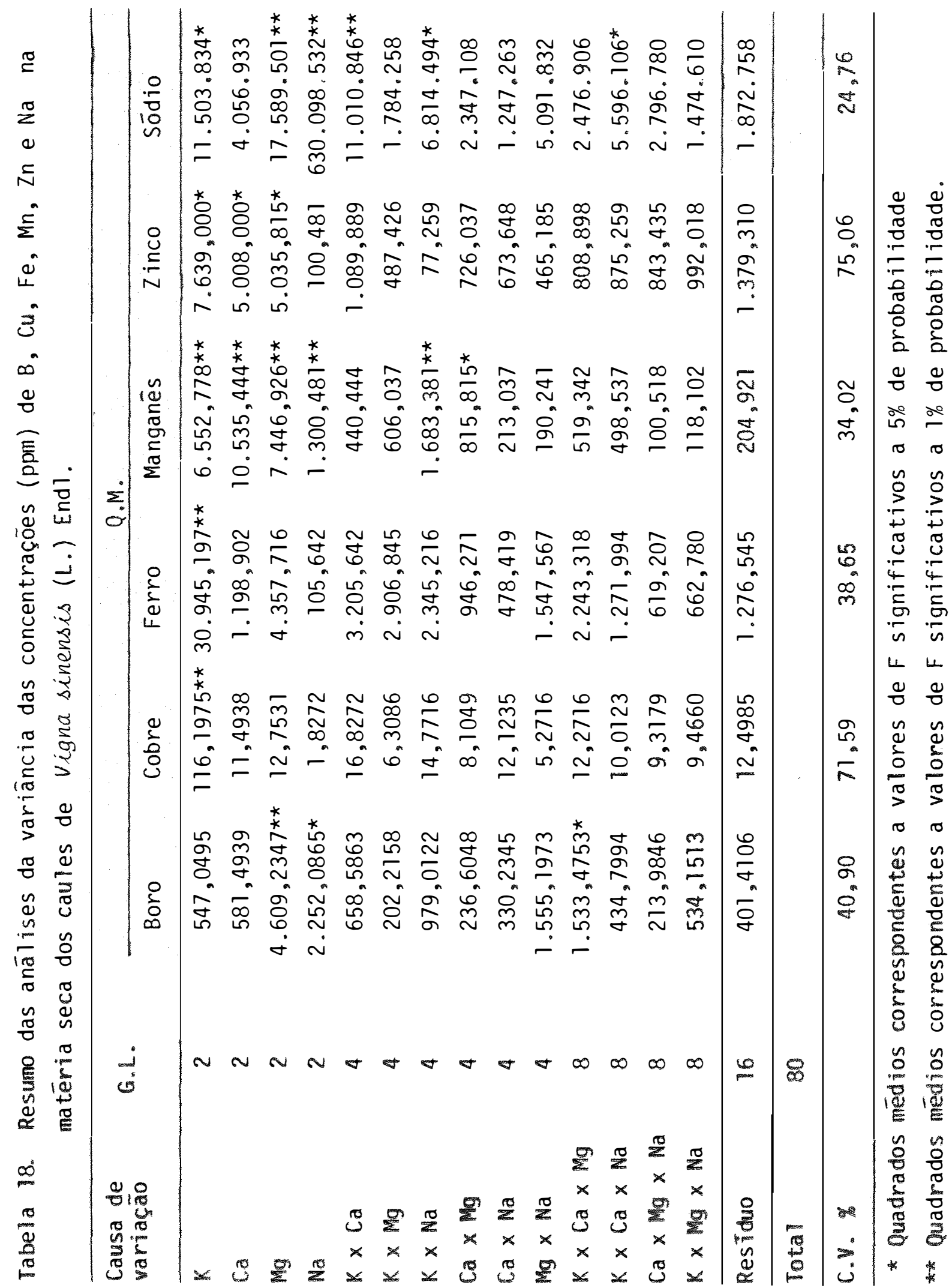


5. DISCUSSÃO

5.1. Produção de Matéria Seca das Folhas e Caules

A produção de matéria seca das folhas em função das doses de potāssio, cālcio e magnésio na solução nutritiva, encontra-se na tabela 19. O efeito do magnésio sobre a produção de matēria seca não fo consistente, ocorrendo aumento ou diminuição de matēria seca pelo fornecimento do elemento à solução nutritiva, em apenas dois tratamentos. Os aumentos de matéria seca pela adição de potāssio, apareceram predominantemente nos tratamentos em que não foi fornecido magnésio à solução nutritiva e somente naqueles em que o cálcio estava presente. A adição de cálcio provocou aumento na produção de matéria seca, excetuando-se os casos em que o potássio e o magnésio estavam li mitando a produção (tratamentos $\mathrm{K}_{0} \mathrm{Mg}_{0}$ ou $\mathrm{K}_{0} \mathrm{Mg}_{24}$ ). DANTAS et alii (1979), observaram que a ausēncia de qualquer macronutriente na solução nutritiva, provocou diminuição na produção de matéria seca das plantas de Vigna sinensis (L.) Endl. 
Tabela 19. Produção de matéria seca ( $g$ ) das folhas de Vigna sinensis ( $L$. ) End1., em função das doses de potássio, cālcio e magnésio na solução nutritiva

\begin{tabular}{|c|c|c|c|c|}
\hline \multirow{2}{*}{$K(p p m)$} & \multirow{2}{*}{$\mathrm{Ca}$ (ppm) } & \multicolumn{3}{|c|}{ Mg (ppm) } \\
\hline & & 0 & 24 & 48 \\
\hline & 0 & 1,96 & 1,70 & 1,85 \\
\hline \multirow[t]{3}{*}{0} & 100 & 1,85 & 3,06 & 4,53 \\
\hline & 200 & 1,48 & 3,75 & 5,44 \\
\hline & 0 & 2,11 & 2,83 & 2,75 \\
\hline \multirow[t]{3}{*}{117} & 100 & 4,93 & 7,72 & 7,43 \\
\hline & 200 & 7,36 & 5,08 & 4,34 \\
\hline & 0 & 2,06 & 2,78 & 2,48 \\
\hline \multirow[t]{2}{*}{234} & 100 & 7,49 & 5,07 & 3,98 \\
\hline & 200 & 6,54 & 6,68 & 6,07 \\
\hline \multicolumn{2}{|c|}{ D.M.S. Tukey $5 \%$} & $\begin{array}{c}\mathrm{K} \\
\mathrm{Ca} \\
\mathrm{Mg}\end{array}$ & $\begin{array}{r}\mathrm{g} \times \mathrm{Ca} \\
\times \mathrm{Mg} \\
\times \mathrm{Ca}\end{array}$ & \\
\hline
\end{tabular}

Nas tabelas 20,21 e 22 são apresentados respectivamente, os efeitos isolados do potássio, cālcio e magnésio sobre a produção de matéria seca dos caules. A adição do primeiro nīvel de cada elemento no substrato, foi suficiente para se obter o māximo de produção de matéria 
seca, embora MUNSON (1968), tenha salientado que as interações produzem mudanças à nỉvel subcelular, que poderão influenciar a fotossintese, respiração, utilização e translocação de carboidratos e ácidos orgânicos.

Tabela 20. Produção de matéria seca dos caules de Vigna sinensis (L.) Endl., em função das doses de potāssio na solução nutritiva

\begin{tabular}{cc}
\hline$K(\mathrm{ppm})$ na solução & Matéria seca $(\mathrm{g})$ \\
\hline 0 & 1,34 \\
117 & 2,91 \\
234 & 2,84 \\
\hline
\end{tabular}

D.M.S. Tukey $5 \%=0,67$ 
Tabela 21. Produção de matéria seca dos caules de Vigna sinensis Endl., em função das doses de cālcio na solução nutritiva

\begin{tabular}{cc}
\hline Ca $(\mathrm{ppm})$ na solução & Matéria seca $(\mathrm{g})$ \\
\hline 0 & 1,34 \\
100 & 2,79 \\
200 & 2,97 \\
\hline \multirow{2}{*}{ D.M.S. Tukey $5 \%=0,67$} & \\
\hline
\end{tabular}

Tabela 22. Produção de matéria seca dos caules de Vigna sinensis (L.) Endl., em função das doses de magnésio na solução nutritiva

Mg (ppm) na solução Matéria seca ( $g$ )

\begin{tabular}{cc}
\hline 0 & 1,92 \\
24 & 2,55 \\
48 & 2,62 \\
\hline D.M.S. Tukey $5 \%=0,67$ & \\
\hline
\end{tabular}


5.2. Concentração de Nutrientes na Matēria Seca em Função das doses de Potássio, Cālcio, Magnésio e Sódio.

5.2.1. Concentração de Nitrogēnio

A influência do potássio sobre a concentração de nitrogēnio na matēria seca das folhas e caules encontra-se na tabela 23 e os efeitos isolados do cálcio e magnésio sobre a concentração de nitrogēnio na matéria seca dos caules nas tabelas 24 e 25 respectivamente. A adição de cāicio ou magnēsio à solução, diminuiu a concentração do nitrogēnio na matéria seca dos caules, enquanto que o potássio afetou da mesma forma, caules e folhas. O efeito de diluição pode explicar em parte as variações assinaladas, uma vez que sempre estiveram relacionadas com o aumento de matéria seca. DANTAS et alii (1979) verificaram que a deficiencia de qualquer macronutriente, exceto a de enxöfre, causou um aumento na porcentagem de nitrogēnio nas folhas de duas variedades de Vigna sinensis (L.) Endl. cultivadas em solução nutritiva. 
Tabela 23. Concentração de nitrogênio na matēria seca das folhas e caules de Vigna sinensis (L.) Endl., em função das doses de potāssio na solução nutritiva

\begin{tabular}{|c|c|c|c|}
\hline \multirow[b]{2}{*}{$K$ (ppm) na solução } & & \multicolumn{2}{|c|}{$N(\%)$ na matéria seca } \\
\hline & & folhas & caules \\
\hline 0 & & 5,12 & 4,13 \\
\hline 117 & & 4,40 & 2,71 \\
\hline 234 & & 4,30 & 2,43 \\
\hline & D.M.S. Tukey $5 \%=$ & 0,49 & 0,29 \\
\hline
\end{tabular}

Tabela 24. Concentração de nitrogēnio na matēria seca dos caules de Vigna sinensis (L.) Endl,, em função das doses de cālcio na solução nutritiva

Ca (ppm) na solução $\quad N(\%)$ na matéria seca

\begin{tabular}{rr}
0 & 3,83 \\
100 & 2,86 \\
200 & 2,58 \\
\hline
\end{tabular}

D.M.S. Tukey $5 \%=0,29$ 
Tabela 25. Concentração de nitrogēnio na matēria seca dos caules de Vigna sinensis (L.) Endl., em função das doses de magnésio na solução nutritiva

$M g$ (ppm) na solução

N (\%) na matērica seca

\begin{tabular}{rc}
\hline 0 & 3,50 \\
24 & 2,96 \\
48 & 2,82 \\
\hline
\end{tabular}

D.M.S. Tukey $5 \%=0,29$

$\mathrm{Na}$ tabela 26, são apresentadas as concentrações de nitrogènio na matéria seca dos caules, em função das doses de sōdio na solução nutritiva. A adição de 184 ppm de sōdio ao substrato, diminuiu o teor de nitrogēnio na matēria seca dos caules, o que não pode ser explicado por efeito de diluição, uma vez que o elemento não afetou a produção de matéria seca dessa parte da planta. Este resultado concorda com os obtidos por WADLEIGH e GAUCH (1942), os quais observaram que a adição de cloreto de sódio ao substrato, está associada com a diminuição de nitrogēnio em plantas de feijão "red kidney". 
Tabela 26. Concentração de nitrogēnio na matéria seca dos caules de Vigna sinensis (L.) Endl., em função das doses de sōdio na solução nutritiva
$\mathrm{Na}$ (ppm) na solução
$N(\%)$ na matéria seca

\begin{tabular}{rc}
\hline 0 & 3,30 \\
92 & 3,07 \\
184 & 2,90 \\
\hline D.M.S. Tukey $5 \%=0,29$ \\
\hline
\end{tabular}

\subsubsection{Concentração de Fōsforo}

As concentrações de fósforo na matéria seca das folhas em função das doses de potássio e cāicio na solução nutritiva são apresentadas na tabela 27. A adição de potássio ou de cárcio ã solução nutritiva, na maioria dos casos provocou diminuição da concentração de fósforo na matéria seca das folhas, que pelo menos parcialmente pode ser explicado pe10 efeito de diluição, uma vez que as plantas nestas condições tiveram maio res acúmulos de matéria seca. DANTAS et alii (1979), observaram aumentos nos teores de fósforo nas folhas de Vigna sinensis (L.) Endl., nos tratamentos com omissão de nitrogēnio, de potássio, de cālcio ou de magnésio, na solução nutritiva, atribuindo a um provāvel efeito de diluição no tratamento completo, onde os teores de fósforo nas folhas foram ma is baixos. 
Tabela 27. Concentração de fósforo (\%) na matéria seca das folhas de Vigna sinensis (L.) Endl., em função das doses de potāssio e cālcio na solução nutritiva

\begin{tabular}{lccc}
\hline & \multicolumn{2}{c}{ Ca $(\mathrm{ppm})$} \\
\cline { 2 - 4 } & 0 & 100 & 200 \\
\hline 0 & 0,93 & 0,76 & 0,82 \\
117 & 0,66 & 0,67 & 0,54 \\
234 & 0,53 & 0,58 & 0,41 \\
\hline & & & \\
D.M.S. Tukey 5\% & Ca dentro de Ca $=0,13$ & \\
\hline
\end{tabular}

As concentrações de fósforo na matéria seca dos caules em função das doses de potássio, cālcio e magnésio na solução nutritiva são apresentadas na tabela 28. De uma forma geral, os efeitos que foram poss vel registrar pela adição de cālcio, potássio ou magnēsio ao substrato, foram de diminuição na concentração de fósforo na matēria seca dos caules. Convēm salientar, que os elementos citados aumentaram também a produção de matéria seca, sugerindo portanto o efeito de diluição. As observações feitas por DANTAS et alii (1979), mencionadas na tabela anterior, também são vālidas para os resultados aqui registrados. 
Tabeia 28. Concentração de fōsforo (\%) na matéria seca dos caules de Vigna sinensis (L.) Endl., em função das doses de potássio, cālcio e magnésio na solução nutritiva

\begin{tabular}{|c|c|c|c|c|}
\hline \multirow{2}{*}{$K(p p m)$} & \multirow{2}{*}{$\mathrm{Ca}$ (ppm) } & \multicolumn{3}{|c|}{$M g(p p m)$} \\
\hline & & 0 & 24 & 48 \\
\hline \multirow{3}{*}{0} & 0 & 0,50 & 0,35 & 0,51 \\
\hline & 100 & 0,47 & 0,46 & 0,44 \\
\hline & 200 & 0,57 & 0,47 & 0.42 \\
\hline \multirow{3}{*}{117} & 0 & 0,50 & 0,42 & 0,42 \\
\hline & 100 & 0,39 & 0,38 & 0,42 \\
\hline & 200 & 0,38 & 0,40 & 0,37 \\
\hline \multirow{3}{*}{234} & 0 & 0,43 & 0,44 & 0,46 \\
\hline & 100 & 0,35 & 0,38 & 0,29 \\
\hline & 200 & 0,37 & 0,32 & 0,24 \\
\hline D.M.S. & Tukey 5\% & $\begin{array}{l}\mathrm{K} \text { dentrc } \\
\mathrm{Ca} \text { dentrc } \\
\text { Mg dentrc }\end{array}$ & $\begin{array}{l}=0,09 \\
=0,09 \\
=0,09\end{array}$ & \\
\hline
\end{tabular}




\subsubsection{Concentração de Potāssio}

$\mathrm{Na}$ tabela 29 são apresentadas as concentrações de potássio na matēria seca das folhas em função das doses de sōdio na solução nutritiva. A adição de 184 ppm de sōdio ao substrato, provocou aumento na concentração de potāssio na matēria seca, o que em parte pode ser explicado pelo efeito de concentração, uma vez que a adição de sódio ao substrato diminuiu a quantidade de matéria seca produzida. WALLACE et alii (1948), observaram que a adição de sōdio à solução nutritiva provocou aumento na concentração de potássio em plantas de alfafa com baixo teor desse elemento, provavelmente devido a substituição nas raỉzes do potāssio pelo sōdio, com seu subsequente movimento para a parte aērea. Por outro lado, BOWER e WADLEIGH (1948), constataram diminuição no acúmulo de potássio nas folhas de feijão "red kidney", somente quando foram adicionadas doses elevadas de sōdio à solução nutritiva.

Tabela 29. Concentração de potāssio na matéria seca das folhas de Vigna sinensis (L.) Endl., em função de doses de sōdio na solução nutritiva

\begin{tabular}{rc} 
Na (ppm) na solução & $K(\%)$ na matēria seca \\
\hline 0 & 3,00 \\
92 & 3,27 \\
184 & D.M.S. Tukey
\end{tabular}


As concentraçōes de potássio na matéria seca das folhas e caules, em função das doses de potássio e cálcio na solução nutritiva, são mostradas nas tabelas 30 e 31 respectivamente. A adição de potässio ao substrato, aumentou a concentração do elemento na matéria seca das foThas e caules. A adição de cálcio na presença de potássio na solução nutritiva, na maioria dos casos diminuiu a concentração de potássio na matéria seca das folhas e caules, sendo que, para os caules o fato se verificou apenas na presença da maior dose de potássio. Provavelmente, o cāl cio afetou por antagonismo a absorção de potássio pelas plantas.

Tabela 30. Concentração de potássio (\%) na matéria seca das folhas de Vigna sinensis (L.) Endl., em função das doses de potássio e cālcio na solução nutritiva

\begin{tabular}{|c|c|c|c|}
\hline \multirow{2}{*}{$\mathrm{K}(\mathrm{ppm})$} & \multicolumn{3}{|c|}{$\mathrm{Ca}$ (ppm) } \\
\hline & 0 & 100 & 200 \\
\hline 0 & 1,49 & 1,34 & 1,15 \\
\hline 117 & 3,74 & 3,10 & 3,37 \\
\hline \multirow[t]{2}{*}{234} & 5,54 & 4,67 & 4,34 \\
\hline & & $\begin{array}{l}=0,5 \\
=0,5\end{array}$ & \\
\hline
\end{tabular}


Tabela 31. Concentração de potāssio (\%) na matēria seca dos caules de Vigna sinensis (L.) Endl., em função das doses de potāssio e cālcio na solução nutritiva

\begin{tabular}{|c|c|c|c|}
\hline \multirow{2}{*}{$K(p p m)$} & \multicolumn{3}{|c|}{$\mathrm{Ca}(\mathrm{ppm})$} \\
\hline & 0 & 100 & 200 \\
\hline 0 & 0,56 & 0,76 & 0,73 \\
\hline 117 & 2,19 & 1,85 & 2,21 \\
\hline 234 & 4,43 & 3,57 & 3,26 \\
\hline D.M.S. Tukey 5\% & & $\begin{array}{l}\mathrm{Ca}=0 \\
\mathrm{~K}=0\end{array}$ & \\
\hline
\end{tabular}

$\mathrm{Na}$ tabela 32 são apresentadas as concentrações de potāssio na matéria seca dos caules em função das doses de cāicio e magnésio na solução nutritiva. A adição de cālcio em presença da maior dose de magnésio, ou a adição da maior dose de magnésio na presença da maior dose de cálcio na solução nutritiva, provocou diminuição na concentração do potássio na matéria seca dos caules, estes resultados são concordantes com os obtidos por EVANS et alii (1950), os quais observaram que o excesso de magnēsio diminuiu drasticamente a concentração de potāssio nas folhas de soja cultivada em solução nutritiva. Segundo Becrett (1971), citado por MALAVOLTA (1976), o cālcio e o magnésio são os dois ionios inibidores mais importantes no processo de absorção de potássio. 
Tabela 32. Concentração de potāssio (\%) na matēria seca dos caules de Vigna sinensis (L.) Endl., em função das doses de cālcio e magnésio na solução nutritiva

\begin{tabular}{cccc}
\hline \multirow{2}{*}{ Ca $(\mathrm{ppm})$} & \multicolumn{3}{c}{ Mg (ppm) } \\
\cline { 2 - 4 } & 0 & 24 & 48 \\
\hline 0 & 2,33 & 2,10 & 2,75 \\
100 & 1,99 & 2,06 & 2,14 \\
200 & 2,35 & 2,09 & 1,76 \\
\hline \multirow{2}{*}{ D.M.S. Tukey $5 \%$} & & Ca dentro de Mg $=0,54$ & \\
& & Mg dentro de Ca $=0,54$ & \\
\hline
\end{tabular}

5.2.4. Concentração de Cálcio

As concentrações de cālcio na matéria seca das folhas em função das doses de potāssio e cālcio na solução nutritiva, encontram-se na tabela 33. A adição de cálcio ao substrato, aumentou a concentração do elemento na matéria seca. A adição da maior dose de potāssio na presença de cālcio na solução nutritiva, provocou diminuição da concentração de cálcio na matéria seca, provavelmente por antagonismo. De acordo com STEWART e REED (1949), a aplicação de potássio no solo, reduziu o nível de cálcio nas plantas de Vigna sinensis (L.) Endl. 
Tabela 33. Concentração de călcio (\%) na matēria seca das folhas de Vigna sinensis (L.) End7., em função das doses de potāssio e cālcio na solução nutrinte

\begin{tabular}{|c|c|c|c|}
\hline \multirow{2}{*}{$K(p p m)$} & \multicolumn{3}{|c|}{$\mathrm{Ca}(\mathrm{ppm})$} \\
\hline & 0 & 100 & 200 \\
\hline 0 & 0,90 & 2,41 & 3,37 \\
\hline 117 & 0,94 & 2,31 & 3,13 \\
\hline 234 & 0,93 & 1,84 & 2,57 \\
\hline D.M.S. Tukey $5 \%$ & & $\begin{array}{l}=0,3 \\
=0,3\end{array}$ & \\
\hline
\end{tabular}

São apresentadas na tabela 34 , as concentrações de cālcio na matēria seca dos caules em função das doses de sōdio na solução nutritiva. A adição de sōdio no substrato, provocou diminuição na concentração de cálcio na matéria seca dos caules. Estes resultados são concordantes com os obtidos por BOWER e WADLEIGH (1948) e WALLACE et alii (1948), para as culturas do feijão e alfafa respectivamente, cultivadas em solução nutritiva. 
Tabela 34. Concentração de cālcio na matēria seca dos caules de Vigna sinensis (L.) Endl., em função das doses de sōdio na solução nutritiva

Na (ppm) na solução

Ca (\%) na matēria seca

\begin{tabular}{rc}
\hline 0 & 0,82 \\
92 & 0,71 \\
184 & 0,61 \\
\hline D.M.S. Tukey $5 \%=0,07$ & \\
\hline
\end{tabular}

As concentrações de cālcio na matēria seca dos caules em função das doses de potássio, cālcio e magnésio na solução nutritiva, são apresentadas na tabela 35. De uma maneira geral, a adição de cālcio ao substrato provocou aumento da concentração do elemento na matéria seca dos caules. A adição de potássio, diminuiu a concentração de cālcio na matēria seca, predominantemente na ausência de magnésio e somente na presença de cālcio na solução nutritiva. A adição de magnésio na presença de cālcio na solução nutritiva, na maioria das vezes diminuiu a concentração de cālcio na matéria seca. Para ambos os casos, a diminuição dos teores de cālcio estiveram associadas ao aumento na matéria seca acumulada, sugerindo pelo menos em parte, um efeito de dil uição. Resultados semelhantes aos descritos acima, foram obtidos por vārios autores, assim LEGGETT e GILBERT (1969), observaram que o conteūdo de cálcio em plantas de soja aumentou substancialmente com a adição do elemento na solução 
nutritiva; SINHA (1961), constatou que a adição de potāssio à solução nutritiva, diminuiu significativamente o conteūdo de cālcio e magnēsio em plantas de soja; STEWART e REED (1969), observaram redução nos teores de cálcio e magnésio em cowpea, com o aumento das doses de potássio no solo; EVANS (1950), constatou que o excesso de magnésio na solução nutritiva, provocou diminuição nos conteúdos de potássio e cālcio das folhas de soja.

Tabela 35. Concentração de cālcio (\%) na matéria seca dos caules de Vigna sinensis (L.) Endl., em função das doses de potāssio, cálcio e magnésio na solução nutritiva

\begin{tabular}{|c|c|c|c|c|}
\hline \multirow{2}{*}{$\mathrm{K}(\mathrm{ppm})$} & \multirow{2}{*}{$\mathrm{Ca}$ (ppm) } & \multicolumn{3}{|c|}{$\mathrm{Mg}(\mathrm{ppm})$} \\
\hline & & 0 & 24 & 48 \\
\hline \multirow{3}{*}{0} & 0 & 0,34 & 0,22 & 0,21 \\
\hline & 100 & 1,39 & 0,67 & 0,75 \\
\hline & 200 & 1,77 & 1,11 & 0,83 \\
\hline \multirow{3}{*}{117} & 0 & 0,34 & 0,21 & 0,16 \\
\hline & 100 & 0,82 & 0,67 & 0,67 \\
\hline & 200 & 1,45 & 1,01 & 0,89 \\
\hline \multirow{3}{*}{234} & 0 & 0,27 & 0,20 & 0,21 \\
\hline & 100 & 0,99 & 0,65 & 0,58 \\
\hline & 200 & 1,25 & 0,94 & 0,66 \\
\hline \multicolumn{2}{|c|}{ D.M.S. Tukey $5 \%$} & $\begin{array}{l}\text { K der } \\
\text { Ca der } \\
\text { Mg der }\end{array}$ & $\begin{array}{l}\mathrm{Mg}= \\
\mathrm{Mg}= \\
\mathrm{Ca}=\end{array}$ & \\
\hline
\end{tabular}




\subsubsection{Concentração de Magnēsio}

$\mathrm{Na}$ tabela 36 são apresentadas as concentrações de magnēsio na matēria seca das folhas em função das doses de cálcio na solução nutritiva. A adição da dose máxima de cālcio, diminuiu a concentração de magnésio nas folhas, o que em parte pode-se atribuir ao efeito de dituição em face do aumento da matēria seca tambēm verificado. Por outro lado, a literatura contēm vārias referēncias sobre o antagonismo magnésio e cā1cio. De acordo com Emmert (1961), citado por EPSTEIN (1975), observações sobre essas interações são particularmente comuns em trabalhos com ārvores frutîferas. DANTAS et alii (1979), constataram aumento na concen tração de magnésio dos tecidos das folhas de Vigna sinensis (L.) Endl., cultivadas na ausēncia de cālcio na solução nutritiva.

Tabela 36. Concentração de magnésio na matēria seca das folhas de Vigna sinensis (L.) Endl., em função das doses de cālcio na solução nutritiva

Ca (ppm) na solução

Mg (\%) na matēria seca

\begin{tabular}{rc}
0 & 0,43 \\
100 & 0,45 \\
200 & 0,39 \\
\hline
\end{tabular}

D.M.S. Tukey $5 \%=0,04$ 
Na tabela 37 são apresentadas as concentrações de magnēsio na matēria seca das folhas, em função das doses de potāssio e magnésio na solução nutritiva. A adição de magnésio ao substrato, provocou aumento na concentração do elemento na matéria seca. De um modo geral, a adição de potāssio à solução nutritiva, diminuiu a concentração de magnēsio na matéria seca, provavelmente o potássio afetou por antagonismo a absorção do magnésio pelas plantas. Resultados semelhantes foram obtidos por SINHA (1961), em soja cultivada em solução nutritiva e por STEWART e REED(1969), em plantas de cowpea em condições de solo.

Tabela 37. Concentração de magnésio (\%) na matēria seca das folhas de Vigna sinensis (L.) Endl., em função das doses de potässio e magnésio na solução nutritiva

\begin{tabular}{|c|c|c|c|}
\hline \multirow{2}{*}{$\mathrm{K}(\mathrm{ppm})$} & \multicolumn{3}{|c|}{$\mathrm{Mg}$ (ppm) } \\
\hline & 0 & 24 & 48 \\
\hline 0 & 0,22 & 0,61 & 0,86 \\
\hline 117 & 0,16 & 0,45 & 0,66 \\
\hline 234 & 0,14 & 0,37 & 0,54 \\
\hline & & $\begin{aligned} M g & = \\
K & =\end{aligned}$ & \\
\hline
\end{tabular}


As concentrações de magnésio na matéria seca dos caules em função das doses de cālcio e magnésio na solução nutritiva, são apresentadas na tabela 38. A adição de magnēsio ao substrato, aumentou a concentração do elemento na matéria seca dos caules. A adição de 100 ppm de cālcio na presença da maior dose de magnésio, aumentou a concentração de magnésio na matéria seca, diminuindo, quando se adicionou 200 ppm de cálcio à solução nutritiva, nas mesmas condições. E bastante conhecido na literatura, que a presença de cālcio em baixas concentrações no substrato estimula a absorção de outros ions, por outro lado, provavelmente a adição da maior dose de cálcio afetou por antagonismo a absorção do magnēsio pelas plantas. DANTAS et alii (1979), constataram que as plantas de Vigna sinensis (L.) Endl., cultivadas em solução nutritiva deficientes em câlcio, apresentaram maiores concentrações de magnésio no tecido, sugerin do a ocorrência de inibição competitiva.

Tabela 38. Concentração de magnésio (\%) na matéria seca dos caules de Vigna sinensis (L.) Endl., em função das doses de cālcio e magnésio na solução nutritiva

\begin{tabular}{cccc}
\hline Ca $(\mathrm{ppm})$ & \multicolumn{3}{c}{ Mg (ppm) } \\
\cline { 2 - 4 } & 0 & 24 & 48 \\
\hline 0 & 0,19 & 0,41 & 0,59 \\
100 & 0,13 & 0,46 & 0,67 \\
200 & 0,15 & 0,41 & 0,53 \\
\hline \multirow{2}{*}{ D.M.S. Tukey 5\% } & Ca dentro de Mg $=0,08$ & \\
& & Mg dentro de $\mathrm{Ca}=0,08$ & \\
\hline
\end{tabular}


$\mathrm{Na}$ tabela 39 são apresentadas as concentrações de magnēsio na matéria seca dos caules em função das doses de potássio e sōdio na solução nutritiva. A adição de potássio, na maioria dos casos, ou a adição de maior dose de sōdio à solução nutritiva, provocou diminuição na concentração de magnésio na matēria seca. A diminuição na concentração de magnēsio pela aplicaçào de potássio, é concordante com os resultados anteriormente mencionados, obtidos por SINHA (196I) e STEWART e REED (1969), com as culturas da soja e cowpea respectivamente. BOWER e WADLEIGH(1948), observaram que a adição de sōdio à solução nutritiva, provocou diminuição na concentração de magnésio na parte aérea de plantas de feijão "red kidney".

Tabela 39. Concentração de magnésio (\%) na matéria seca dos caules de Vigna sinensis (L.) Endl., em função das doses de potássio e sōdio na solução nutritiva

\begin{tabular}{|c|c|c|c|}
\hline \multirow{2}{*}{$K(p p m)$} & \multicolumn{3}{|c|}{$\mathrm{Na}$ (ppm) } \\
\hline & 0 & 92 & 184 \\
\hline 0 & 0,60 & 0,43 & 0,42 \\
\hline 117 & 0,41 & 0,39 & 0,33 \\
\hline \multirow[t]{2}{*}{234} & 0,36 & 0,34 & 0,28 \\
\hline & & $\begin{array}{l}=0, \\
=0,0\end{array}$ & \\
\hline
\end{tabular}




\subsubsection{Concentração de Enxōfre}

Os efeitos isolados do potássio, cālcio e sōdio sobre as concentraçōes de enxōfre na matēria seca das folhas, são apresentados nas tabelas 40,41 e 42 respectivamente. A adição de potássio ao substrato au mentou a concentração do enxôfre na matēria seca das folhas. A adição da maior dose de cálcio ou de 92 ppm de sódio à solução nutritiva, provocou diminuição na concentração de enxōfre na matēria seca das folhas, entretanto WALLACE et alii (1948), constataram que o conteūdo de enxōfre da alfafa não foi influenciado pela adição de södio na solução nutritiva. De acordo com MENGEL e KIRKBY (1979), outros nutrientes afetam muito pouco a absorção de sulfato pelas cēlulas das plantas.

Tabela 40. Concentração de enxōfre na matéria seca das folhas de Vigna sinensis (L.) Endl., em função das doses de potássio na solução nutritiva

\begin{tabular}{cc}
$K(\mathrm{ppm})$ na solução & $S(\%)$ na matéria seca \\
\hline 0 & 0,27 \\
117 & 0,33 \\
234 & 0,33 \\
\hline
\end{tabular}

$$
\text { D.M.S. Tukey } 5 \%=0,05
$$


Tabela 41. Concentração de enxôfre na matēria seca das folhas de Vigna sinensis (L.) Endl., em função das doses de cālcio na solução nutritiva

\begin{tabular}{cc} 
Ca $(\mathrm{ppm})$ na solução & S $(\%)$ na matéria seca \\
\hline 0 & 0,36 \\
100 & 0,32 \\
200 & 0,25 \\
\hline
\end{tabular}

D.M.S. Tukey $5 \%=0,05$

Tabela 42. Concentração de enxōfre na matéria seca das folhas de Vigna sinensis (L.) Endl., em função das doses de södio na solução nutritiva

\begin{tabular}{|c|c|c|}
\hline $\mathrm{Na}(\mathrm{ppm})$ na solução & $S(\%)$ & na matéria seca \\
\hline 0 & & 0,34 \\
\hline 92 & & 0,29 \\
\hline 184 & & 0,30 \\
\hline
\end{tabular}

D.M.S. Tukey $5 \%=0,05$ 
As concentraçōes de enxōfre na matéria seca dos caules, em função das doses de potássio e sōdio na solução nutritiva, são apresentadas na tabela 43. A adição de sōdio ao substrato afetou a concentração do enxōfre na matéria seca, apenas quando se passou de 92 para 184 ppm do elemento adicionado ao substrato, na presença da primeira dose de potássio. A adição de potāssio, na maioria das vezes diminuiu a concentração do enxôfre na matéria seca dos caules, sugerindo efeito de diluição, tendo em vista que a adição de potássio ao substrato, tambēm provocou aumento da matéria seca nos tratamentos considerados.

Tabela 43. Concentração de enxōfre (\%) na matēria seca dos caules de Vigna sinensis (L.) End T., em função das doses de potāssio e sōdio na solução nutritiva

\begin{tabular}{lccc}
\hline$K(p p m)$ & \multicolumn{2}{c}{$N a(p p m)$} & 184 \\
\cline { 2 - 4 } & 0 & 92 & 0,61 \\
0 & 0,61 & 0,55 & 0,44 \\
117 & 0,50 & 0,52 & 0,41 \\
234 & 0,46 & 0,41 & \\
\hline \multirow{2}{*}{ D.M.S. Tukey 5\% } & K dentro de $\mathrm{Na}=0,07$ & \\
\hline
\end{tabular}


As concentraçōes de enxōfre na matēria seca dos caules em função das doses de potāssio, cālcio e magnésio na solução nutritiva, são apresentadas na tabela 44. A adição de potässio ao substrato, na maioria das vezes diminuiu a concentração do enxōfre na matéria seca dos caules. A adição de cálcio na auséncia de potássio e somente na presença de magnē sio, bem como, a adiçào de magnésio predominantemente na ausēncia de potāssio na solução nutritiva, na maioria dos casos, diminuiram a concentração de enxōfre na matéria seca. Todos os resultados observados podem ser atribuidos ao efeito de diluição, o que vem comprovar a observação feita por MENGEL e KIRKBY (1979), segundo a qual, outros nutrientes afetam muito pouco a absorção de sulfato pelas células das plantas. 
Tabela 44. Concentração de enxōfre (\%) na matéria seca dos caules de Vigna sinensis (L.) Endl., em função das doses de potāssio, cālcio e magnésio na solução nutritiva

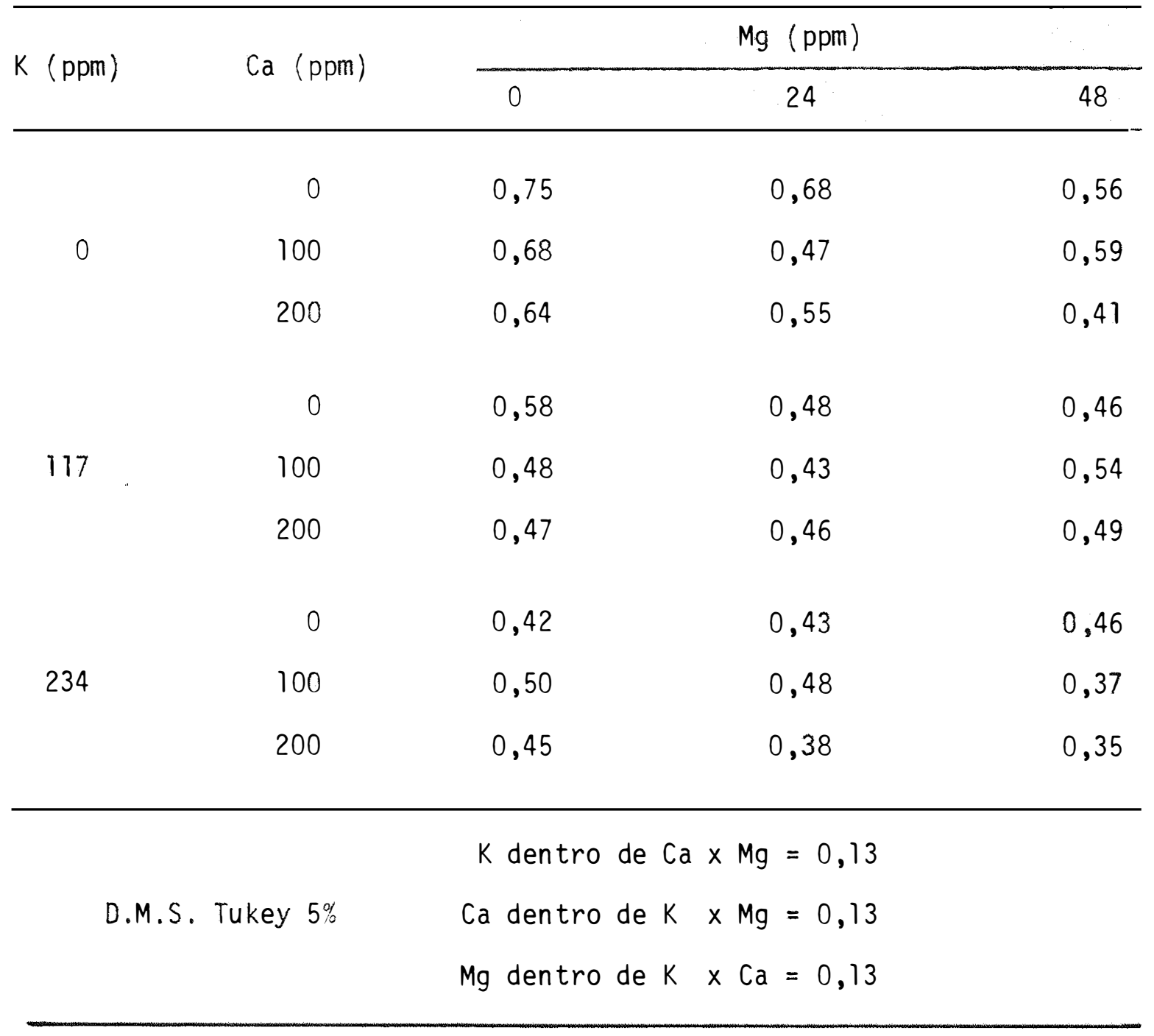




\subsubsection{Concentração de Boro}

Na tabela 45 são apresentadas as concentrações de boro na matéria seca dos caules em função das doses de sōdio na solução nutritiva. A adição de 184 ppm de sōdio à solução, aumentou a concentração de boro na matēria seca. Em condições de campo, segundo RICHARDS (1974), a maior absorção de boro, se dá geralmente em āres limitadas e esparsas de regiões āridas e semi-āridas e, embora a incidēncia não esteja confinada aos solos salinos e sódicos, o excesso de boro é frequente nestes tipos de solos.

Tabela 45. Concentração de boro na matéria seca dos caules de Vigna sinensis (L.) Endl., em função das doses de sōdio na solução nutritiva

\section{D.M.S. Tukey $5 \%=14$}

As concentrações de boro na matēria seca dos caules em função das doses de potássio, cālcio e magnésio na solução nutritiva, são apresentadas na tabela 46. A adição da primeira dose de potássio ou de 
cāicio na ausēncia do outro e do magnésio no substrato, aumentou o teor de boro na matéria seca.

Tabela 46. Concentração de boro (ppm) na matéria seca dos caules de Vigna sinensis (L.) End1., em função das doses de potássio, cālcio e magnésio na solução nutritiva

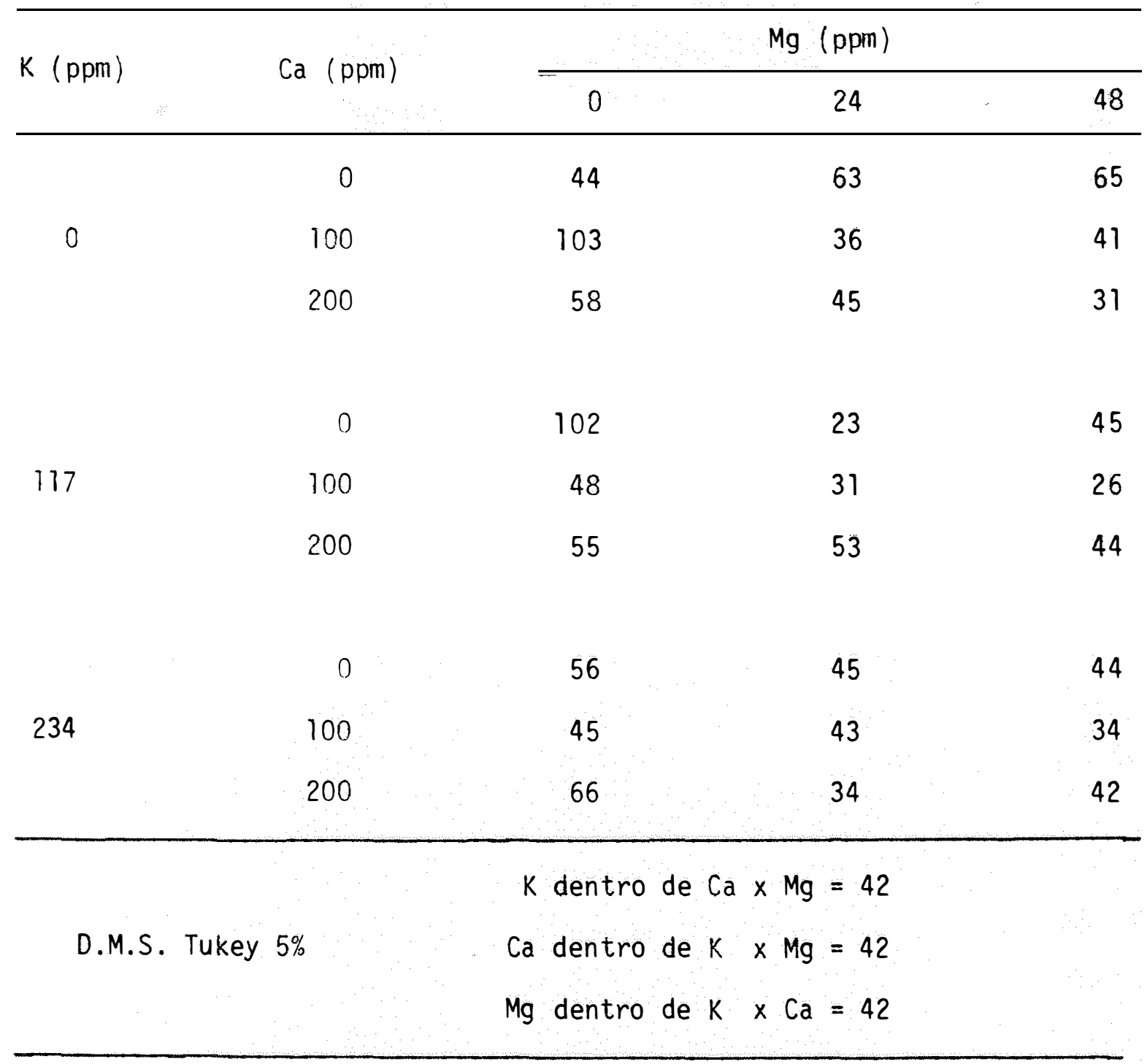




\subsubsection{Concentração de Cobre}

A tabela 47 apresenta as concentrações de cobre na matéria seca das folhas e caules em função das doses de potássio na solução nutritiva. A adição de 234 ppm de potássio ao substrato diminuiu a concentração de cobre na matéria seca das folhas, o mesmo se aplicando aos caules pela adição de qualquer dose de potássio ã solução nutritiva. 0 efei to de diluição pode justificar em parte, as variações ocorridas. Estes resultados, por outro lado, contrariam aqueles obtidos por EVANS et alii (1950), os quais constataram menores concentrações de cobre nas folhas de soja, cultivadas em solução nutritiva deficiente em potássio.

Tabela 47. Concentração de cobre na matéria seca das folhas e caules de Vigna sinensis (L.) Endl., em função das doses de potássio na solução nutritiva

\begin{tabular}{ccc}
\hline K (ppm) na solução & \multicolumn{2}{c}{$\mathrm{Cu}(\mathrm{ppm})$ na matéria seca } \\
\cline { 2 - 3 } & folhas & caules \\
\hline 117 & 7 & 5 \\
234 & 7 & 3 \\
\hline & 6 & 2 \\
\hline
\end{tabular}




\subsubsection{Concentração de Ferro}

Na tabela 48 são apresentadas as concentrações de ferro na matéria seca das folhas, em função das doses de potássio e cálcio na solução nutritiva. A adição da primeira dose de potássio na presença da primeira dose de cálcio no substrato, provocou aumento na concentração de ferro na matéria seca das folhas, entretanto, a adição de cálcio na maioria dos casos, ou da maior dose de potássio à solução nutritiva, provocou diminuição na concentração de ferro na matéria seca, sugerindo efeito de diluição. Por outro lado, efeito competitivo na absorção do ferro pelo potássio, cálcio, magnésio e outros cátions, foram observados por LINGLE et alii (1963), em plantas de soja cultivadas em solução nutritiva. MENGEL e KIRKBY (1979), relataram que a absorção de ferro é consideravelmente influenciada por outros cátions.

Tabela 48. Concentração de ferro (ppm) na matéria seca das folhas de Vigna sinensis (L.) Endl., em função das doses de potássio e cálcio na solução nutritiva

\begin{tabular}{|c|c|c|c|}
\hline \multirow{2}{*}{$\mathrm{K}(\mathrm{ppm})$} & \multicolumn{3}{|c|}{$\mathrm{Ca}(\mathrm{ppm})$} \\
\hline & 0 & 100 & 200 \\
\hline 0 & 353 & 214 & 176 \\
\hline 117 & 302 & 341 & 109 \\
\hline 234 & 211 & 122 & 63 \\
\hline D.M.S. Tukey $5 \%$ & & & \\
\hline
\end{tabular}


As concentraçōes de ferro na matéria seca das folhas em função das doses de potāssio e magnēsio na solução nutritiva, são apresen tadas na tabela 49. A adição ao substrato, da maior dose de potássio, exceto para a maior dose de magnésio, ou da maior dose de magnésio na ausência de potássio, provocou diminuição na concentração de ferro na matéria seca. Observa-se tambēm, que a adição da primeira dose de potássio na presença da maior dose de magnésio, aumentou a concentração de ferro na matēria seca das folhas. Efeito competitivo na absorção do ferro com potássio, cálcio, magnēsio e outros cátions, foram observados por LINGLE et alii (1963), em plantas de soja, jā mencionados anteriormente; entretanto, pela anālise dos dados de matéria seca, as variações verificadas podem ser em parte explicadas pelo efeito de diluição.

Tabela 49. Concentração de ferro (ppm) na matéria seca das folhas de Vigna sinensis (L.) Endl., em função das doses de potāssio e magnésio na solução nutritiva

K (ppm)

$\operatorname{Mg}(p p m)$

0

\begin{tabular}{lccc}
\hline 0 & 308 & 243 & 192 \\
117 & 229 & 241 & 283 \\
234 & 147 & 116 & 134 \\
\hline & & $K$ dentro de $M g=89$ \\
& & Mg dentro de $\mathrm{K}=89$
\end{tabular}


As concentrações de ferro na matéria seca dos caules, em função das doses de potāssio na solução nutritiva, encontram-se na tabela 50. A adição de potāssio ao substrato, diminuiu a concentração de ferro na matéria seca dos caules, o que em parte pode ser explicado pelo efeito de diluição e também pelo efeito de competição, conforme LINGLE et alii (1963), anteriormente citado para folhas.

Tabela 50. Concentração de ferro na matéria seca dos caules de Vigna. sinensis (L.) Endr., em função das doses de potāssio na soTução nutritiva

$K(p p m)$ na solução

Fe (ppm) na matéria seca

\begin{tabular}{lc}
\hline 0 & 131 \\
117 & 74 \\
234 & 71 \\
\hline D.M.S. Tukey $5 \%=25$ \\
\hline
\end{tabular}

\subsubsection{Concentração de Manganēs}

As concentrações de manganēs na matēria seca das folhas, em função das doses de potāssio na solução nutritiva, são apresentadas na tabela 51. A adição de potāssio ao substrato, provocou diminuição na concentração de manganēs na matéria seca das folhas, tais variações podem, 
pelo menos parcialmente ser explicadas pelo efeito de diluição. Por outro lado, foram constatadas por EVANS et alii (1950), deficiēncia de manganés nas folhas de soja cultivadas em solução nutritiva deficiente em potāssio, contrariando assim, os resultados observados.

Tabela 51. Concentração de manganēs na matēria seca das folhas de Vigna sinensis (L.) Endl., em função das doses de potássio na solução nutritiva

$K(p p m)$ na solução

$M n$ (ppm) na matēria seca

0

246

117

172

234

164

$\mathrm{Na}$ tabela 52, são apresentadas as concentrações de manganēs na matēria seca das folhas, em função das doses de cálcio e magnēsio na solução nutritiva. A menor concentração de manganēs, foi obtida na presença das maiores doses de cālcio e de magnésio, aplicadas simultaneamente, sugerindo um efeito competitivo e somatório dos elementos em questão. 
Tabela 52. Concentração de manganēs (ppm) na matēria seca das folhas de Vigna sinensis (L.) Endl., em função das doses de cālcio e magnēsio na solução nutritiva

\begin{tabular}{|c|c|c|c|}
\hline \multirow{2}{*}{$\mathrm{Ca}$ (ppm) } & \multicolumn{3}{|c|}{$\mathrm{Mg}(\mathrm{ppm})$} \\
\hline & 0 & 24 & 48 \\
\hline 0 & 239 & 189 & 223 \\
\hline 100 & 209 & 213 & 292 \\
\hline 200 & 202 & 156 & 121 \\
\hline & & $\begin{array}{l}\text { Ca dentro de } \mathrm{Mg}=51 \\
\text { Mg dentro de } \mathrm{Ca}=51\end{array}$ & \\
\hline
\end{tabular}

$\mathrm{Na}$ tabela 53 são apresentadas as concentração de manganês na matéria seca dos caules em função das doses de cālcio e magnésio na solução nutritiva. A adição tanto de cálcio como de magnésio à solução nutritiva, na maioria das vezes diminuiu a concentração de manganês na matéria seca dos caules, o que em parte, pode ser atribuido ao efeito de diluição. O efeito competitivo sugerido anteriormente para as folhas, tambēm aparece no presente caso. 
Tabela 53. Concentração de manganēs (ppm) na matéria seca dos caules de Vigna sinensis (L.) Endl.. em função das doses de cálcio e magnēsio na solução nutritiva

$\mathrm{Ca}(\mathrm{ppm})$

$M g(p p m)$

\begin{tabular}{lccc}
\hline 0 & 95 & 48 & 49 \\
100 & 51 & 28 & 31 \\
200 & 38 & 24 & 15 \\
\hline & Ca dentro de $\mathrm{Kg}=17$ \\
D.M.S. Tukey 5\% & Mg dentro de $\mathrm{Ca}=17$
\end{tabular}

As concentrações de manganēs na matēria seca dos caules, em função das doses de potāssio e sōdio na solução nutritiva, são apresentadas na tabela 54. A maior concentração de manganês, foi obtida para o tratamento com omissão de potássio e sōdio simultaneamente. A adição de um ou outro elemento isoladamente, provocou diminuição da concentração de manganēs na matēria seca dos caules. A menor concentração de manganês foi obtida pelas maiores doses de potássio e sōdio aplicadas simultaneamente. Tais fatos, sugerem um efeito de antagonismo somatōrio na absorção do manganês, pela aplicação dos elementos em questão. 
Tabela 54. Concentração de manganēs (ppm) na matéria seca dos caules de Vigna sinensis (L.) Endl., em função das doses de potássio e sōdio na solução nutritiva

\begin{tabular}{lccc}
\hline$K(p p m)$ & \multicolumn{3}{c}{ Na $(p p m)$} \\
\cline { 2 - 4 } & 0 & 92 & 184 \\
\hline 0 & 85 & 46 & 49 \\
117 & 29 & 38 & 35 \\
234 & 36 & 31 & 29 \\
\hline \multirow{2}{*}{ D.M.S. Tukey 5\% } & K dentro de $\mathrm{Na}=17$ & \\
& Na dentro de $\mathrm{K}=17$ & \\
\hline
\end{tabular}

\subsubsection{Concentração de Zinco}

Na tabela 55 são apresentadas as concentrações de zinco na matéria seca das folhas e caules em função das doses de cálcio na solução nutritiva, e nas tabelas 56 e 57 respectivamente, aparecem as concentrações de zinco na matēria seca dos caules em função das doses de potássio e magnésio na solução nutritiva. A adição da maior dose de cālcio diminuiu a concentração de zinco na matéria seca das folhas e caules. Entretanto, a diminuição da concentração de zinco nos caules, foi evidenciada apenas pela anālise da variância, uma vez que pela comparação de médias, os valores não alcançaram a diferença minnimia significativa. 
A adição de potássio ou da maior dose de magnésio ao substrato diminuiu a concentração de zinco na matéria seca dos caules. Em todos os casos, pode-se atribuir pelo menos em parte, ao efeito de diluição, em face do aumento de matéria seca das folhas e caules, quando foram adicionados os respectivos elementos à solução nutritiva, CHUDHRY e LONERAGAN (1972), observaram efeito depressivo do cālcio e magnésio na absorção do zinco em outra espécie (trigo), cultivada em solução nutritiva.

Tabela 55. Concentração de zinco na matéria seca das folhas e caules de Vigna sinensis (L.) Endl., em função das closes de cālcio na solução nutritiva

Ca (ppm) na solução

Zn (ppm) na matéria seca

folhas

caules

\begin{tabular}{rcc}
\hline 0 & 69 & 65 \\
100 & 61 & 44 \\
200 & 47 & 40 \\
\hline D.M.S. Tukey $5 \%=$ & 19 & 26 \\
\hline
\end{tabular}


Tabela 56. Concentração de zinco na matéria seca dos caules de Vigna sinensis (L.) Endl., em função das doses de potāssio na solução nutritiva

\begin{tabular}{|c|c|}
\hline$K(p p m)$ na solução & Zn (ppm) na matéria seca \\
\hline 0 & 69 \\
\hline 117 & 37 \\
\hline 234 & 43 \\
\hline
\end{tabular}

$$
\text { D.M.S. Tukey } 5 \%=26
$$

Tabela 57. Concentração de zinco na matéria seca dos caules de Vigna sinensis (L.) Endl., em função das doses de magnésio na solução nutritiva

\begin{tabular}{lc}
$M g(\mathrm{ppm})$ na solução & Zn $(\mathrm{ppm})$ na matéria seca \\
\hline 0 & 65 \\
24 & 45 \\
48 & 39 \\
\hline & D.M.S. Tukey $5 \%=26$ \\
\end{tabular}




\subsubsection{Concentração de Sōdio}

$\mathrm{Na}$ tabela 58 são apresentadas as concentrações de sōdio na matēria seca das folhas em função das doses do elemento na solução nutritiva. A adição de 184 ppm de sōdio à solução provocou aumento na concentração do elemento na matēria seca das folhas, tambēm, AYouB (1974), observou efeitos semelhantes em feijão Phaseolus vulgaris L., cultivado em condições de solo.

Tabela 58. Concentração de sōdio na matēria seca das folhas de Vigna sinensis (L.) Endl., em função das doses de sōdio na solução nutritiva

$\mathrm{Na}$ (ppm) na solução

$\mathrm{Na}(\mathrm{ppm})$ na matéria seca

As concentrações de sōdio na matēria seca das folhas em função das doses de potássio e cálcio na solução nutritiva, são apresentadas na tabela 59. A maior concentração de sōdio na matéria seca, apareceu no tratamento sem potássio e cālcio. A aplicação de cālcio ou 
potássio ao substrato, provocou diminuição no teor de sódio na matéria se ca, fato esse que pode ser atribuido pelo menos em parte, ao efeito de diluição, provocado pelo maior crescimento das plantas. WALLACE et alii (1948), observaram que plantas de alfafa, supridas com grandes quantidades de potássio na solução nutritiva, absorveram reduzidas quantidades de sōdio. AYOUB (1974), constatou que os teores de sōdio das raízes e parte aérea de feijão Phaseolus vulgaris L., diminuiram significativamente, quando foram aumentados os nīveis de cālcio no solo.

Tabela 59. Concentração de sōdio (ppm) na matēria seca das folhas de Vigna sinensis (L.) Endl., em função das doses de potássio e cāicio na solução nutritiva

\begin{tabular}{rrrr}
\hline$K(p p m)$ & \multicolumn{1}{c}{ Ca (ppm) } \\
\cline { 2 - 4 } & 0 & 100 & 200 \\
\hline 117 & 978 & 422 & 447 \\
234 & 690 & 709 & 584 \\
\hline & 417 & 671 & 696 \\
& D.M.S. Tukey 5\% & K dentro de Ca $=408$ & \\
\hline
\end{tabular}


$\mathrm{Na}$ tabela 60 , são apresentadas as concentrações de sōdio na matéria seca dos caules em função das doses de magnésio na solução nutritiva. A adição de magnésio à solução diminuiu a concentração de sódio na matéria seca dos caules, o que em parte pode-se atribuir ao efeito de diluição.

Tabela 60. Concentração de sōdio na matéria seca dos caules de Vigna sinensis (L.) Endl, em função das doses de magnésio na solução nutritiva

\begin{tabular}{cc}
$M g(p p m)$ na solução & $N a(p p m)$ na matëria seca \\
\hline 0 & 6449 \\
24 & 5193 \\
48 & 4942
\end{tabular}

D.M.S. Tukey $5 \%=961$

As concentrações de sōdio na matēria seca dos caules, em função das doses de potássio, cālcio e sódio na solução nutritiva, são apresentadas na tabela 61 . Os resultados mostram, que a absorção de sōdio em condições de alta concentração do elemento no substrato, é afetada pela interação $\mathrm{Ca} \times \mathrm{K}$, que pode deprimir ou aumentar essa absorção. A maior concentração de sódio foi obtida para a maior dose do elemento no substrato e em condições de ausēncia de cālcio e potássio. Comparando-se 
com esse tratamento, a aplicação isolada de cálcio em qualquer dose ou de potássio na maior dose, diminuiu a concentração de sōdio na matēria seca dos caules. Ainda, dentro da maior dose de sódio, a aplicação da dose in termediāria de potássio, na presença de cālcio, aumentou a concentração de sōdio nos tecidos.

Tabela 61. Concentração de sōdio (ppm) na matéria seca dos caules de Vigna sinensis (L.) Endl,, em função das doses de potássio, cálcio e sōdio na solução nutritiva

\begin{tabular}{|c|c|c|c|c|}
\hline \multirow{2}{*}{$K(p p m)$} & \multirow{2}{*}{$\mathrm{Ca}$ (ppm) } & \multicolumn{3}{|c|}{$\mathrm{Na}$ (ppm) } \\
\hline & & 0 & 92 & 184 \\
\hline & 0 & 425 & 7316 & 13093 \\
\hline \multirow[t]{3}{*}{0} & 100 & 255 & 5232 & 7741 \\
\hline & 200 & 425 & 4168 & 7146 \\
\hline & 0 & 510 & 6380 & 10885 \\
\hline \multirow[t]{3}{*}{117} & 100 & 595 & 5955 & 13600 \\
\hline & 200 & 681 & 6292 & 11605 \\
\hline & 0 & 638 & 6295 & 7698 \\
\hline \multirow[t]{2}{*}{234} & 100 & 595 & 6167 & 9610 \\
\hline & 200 & 468 & 5529 & 9950 \\
\hline \multicolumn{2}{|c|}{ D.M.S. Tukey $5 \%$} & $\begin{array}{c}\mathrm{K} \\
\mathrm{Ca} \\
\mathrm{Na}\end{array}$ & $\begin{array}{l}\times \mathrm{Na} \\
\times \mathrm{Na} \\
\times \mathrm{Ca}\end{array}$ & \\
\hline
\end{tabular}


6. CONCLUSÕES

\subsection{Matéria Seca}

- A máxima produção de matéria seca dos caules foi alcançada com concentraçōes de 117, 100 e 24 ppm de potássio, cālcio e magnésio respectivamente, na solução nutritiva. Os aumentos de matéria seca das folhas provocados pela aplicação destes elementos, foram resultado de interação tripla entre os mesmos.

- Não foi possível detectar efeitos da aplicação de atē 184 ppm de sōdio, na produção de matéria seca de qualquer parte da plan ta.

6.2. Concentração de Nutrientes

- A aplicação de potássio, cāicio, magnésio ou sódio, aumentou a concentração do elemento em questão, na ma téria seca dos cau les e folhas das plantas. 
- Os efeitos registrados pela aplicação de potássio na solução nutritiva, foram de diminuição das concentraçōes dos dema is ele mentos na matéria seca das plantas, com exceção do enxōfre e ferro nas fol has e do boro nos caules.

- Os efeitos registrados pela aplicação de cálcio ou magnésio na solução nutritiva, foram de diminuição das concentração dos demais elementos na matēria seca das plantas, com exceção do boro nos caules.

- O comportamento do sōdio aplicado à solução nutritiva, foi semelhante ao do cālcio ou magnésio, sendo registrado ainda, aumento da concentração de potāssio nas folhas, quando o elemento em questão foi aplicado na dose de 184 ppm. 
ADAPETU, J.A. e L.K. AXAPA, 1977. Root growth and uptake characteristics of some cowpea varieties. Agronomy Journal, Madison, 69:940-943.

AYOUB, A.T., 1974. Effect of calcium on sodium salinization of beans (Phase lus vulgaris L.). Journal of Experimental Botany, Oxford. 25 $(85): 245-252$.

BALASUBRAMANIAN, V. e S.K.SINHA, 1976. Effects of salt stress on growth, nodulation and nitrogen fixation in cowpea and mug beans. Physiologia. Plantarum, Copenhagen, 36:197-200.

BOWER, C.A. e C.H.WADLEIGH, 1948. Growth and cationic accumulation by four species of plants as influenced by various levels of exchangeable sodium. Proceedings. Soil Science Society America. Madison, 13:218223. 
BURKART, A., 1943. Las leguminosas argentinas, silvestres y cultivadas. Buenos Aires, Acme Agency. 590 p.

CAMPOS, G.M. e J.H.DAMASCENO, 1973. Adubação mineral na cultura do feijão-de-corda (Vigna sinensis Endl.) em Pentencoste, Cearā. Boletim. Técnico. DNOCS, Fortaleza, 31 (2):101-107.

CHAUDHRY, F.M. e J.F.LONERAGAN, 1972. Zinc absorption by wheat seed 7 ings: I. Inhibition by macronutrient ions in short-term experiments and its relevance to long-term zinc nutrition. Proceedings. Soil Science. Society of America, Madison, 36:323-327.

CHESNEY, H.A.D., 1974. Performance of cowpeas CV 'Black-eye' in Guiana as affected by phosphorus and potassium. Turrialba, 24(2):193-199.

DANTAS, J.P., 1978. Nutrição Mineral do feijão macassar (Vigna sinensis (L.) Endl.). Piracicaba, ESALQ/USP. 121 p. (Dissertação de Mestrado).

DANTAS, J.P., H.BERGAMIN FILHO e E.MALAVOLTA, 1979. Estudos sobre a nútrição mineral do feijão macassar (Vigna sinensis (L.) Endl.). II Efei tos das carências de macronutrientes no crescimento, produção e composição mineral. Anais da E.S.A. "Luiz de Queiroz", Piracicaba, 26: $247-257$. 
EPSTEIN, E., 1975. Nutrição mineral das plantas; princípios e perspectivas. Trad. E.Malavolta. Rio de Janeiro, Livros Técnicos e Cientificos; São Pauto, Ed. USP. 344 p.

EVANS, C.E.; D.J.LATHWELL e H.J.MEDERSKI, 1950. Effect of deficient or toxic levels of nutrients in solution on foliar symptoms and mineral content of soybean leaves as measured by spectrographic methods. Agronomy Journal, Washington, 42:25-32.

FAO, 1980. FAO production yearbook, 1979. Rome, v.33.

GODFREY-SAM-AGGREY, W., 1973. Effect of fertilizers on harvest time and yield of cowpeas (Vigna unguiculata) in Sierra Leone. Experimental. Agriculture, London, 9:315-320.

JAQUINOT, L., 1967. Croissances et alimentations mineral is comparées de quatre variētés de "niēbé" (Vigna unguiculata Waip.). Agronomie Tropicale, Paris, 22(6-7):575-640.

JUNQUEIRA, P.C.; L.F.B.CANCEGLIERO; M.MATSUNAGA e C.T.YAMAGUISHI, 1972. Aspectos econōmicos da produção e comercialização do feijão. In: Anais do I Simpōsio Brasileiro de Feijão, Campinas, São Paulo, Ministério da Agricultura, v.2, p.573-626. 
KASHIRAD, A.; A. BASSIRI e M. KHRADNAM, 1978. Responses of cowpeas applications of $P$ and $F e$ in calcareous soils. Agronomy Journal. Washington, 70:67-70.

LEGGETT, J.E. e W.A. GILBERT, 1969. Magnesium uptake by soybeans, Plant. Physiology, Lancaster, 44:1182-1186.

LEMOS, J.W.V. e J.J.PONTE, 1978. Cultivares de feijão-de-corda Vigna sinensis (L.) Savi., resistentes a melodoiginose. Boletim Cearense de Agronomia, Fortaleza, 19:1-19.

LINGLE, J.C., L.O. TIFFIN e J.C.BROWN, 1963, Iron uptake transport of soybeans as influenced by other cations. Plant Physiology, Lancaster, $\underline{38}(1): 71-76$.

MALAVOLTA, E., 1976. Manual de química agrīcola. São Paulo, Editora Agronōmica Ceres. 528 p.

MALOTH, S. e R.PRASAD, 1976. Relative efficiency of rock phosphate and superphosphate for cowpea (Vigna sinensis Savi.) fooder. Plant and. Soil, The Hague, 45:295-300.

MEDINA, J.C., 1972. Feijão aspectos gerais. In: Anais do I Simpōsio Bra sileiro de Feijão, Campinas, São Paulo, Ministērio da Agricultura, v.l, p.3-106. 
MENGEL, K. e E.A.KIRKBY, 1979. Principles of plant nutrition. 2.ed. Bern, International Potash Institute. Cap. 8 e 13, p.329-346,425-439.

MUNSON, R.D., 1968. Interation of potassium and other ions. In: KILMER, V.J.; S.E.YOUNTS e N.C.BRADY, ed. The Role of Potassium in Agriculture. Madison, American Society of Agronomy, Crop Science Society of America, Soil Science Society of America. p.321-353.

PAIVA, J.B.; J.J.L.ALBUQUERQUE e F.F.BEZERRA, 1971. Adubação mineral em feijão-de-corda (Vigna sinensis Endl.) no Cearä-Brasil, Ciência Agronômica, Fortaleza, I(2):75-78.

PAIVA, J.B.; J.F.ALVES e J.N.E.FROTA, 1973. Adubação nitrogenada e fosfatada em feijão-de-corda Vigna sinensis (L.) Savi. Ciência Agronômica, Fortaleza, $\underline{3}(1 / 2): 55-60$.

PAIVA, J.B.; J.J.L.ALBUQUERQUE e F.F.BEZERRA, 1974. Efeito de espaçamento e adubação em feijão-de-corda, Vigna sinensis (L.) Savi. Ciência. Agronômica, Fortaleza, $\underline{4}(1 / 2): 79-83$.

PIMENTEL GOMES, F. 1973. Curso de estatística experimental. 5.ed. São Paulo, Nobel. $530 \mathrm{p}$.

RICHARDS, L.A., 1974. Diagnostico y rehabilitacion de suelos salinos y sodicos. 6.ed. México, Editorial Limusa. $160 \mathrm{p}$. 
SANCHEZ, P.C. e R.A.R.MATA, 1972. Efecto del mëtodo de colocaciōn, fuente $y$ dosis de fösforo sobre el rendimiento del mani (Arachis hipogaea L.) y del frijol (Vigna sinensis Endl.) en un suelo franco arenoso de sabana. Fitotecnia Latinoamericana, San Josē, 8(3):78-84,

SARRUGE, J.R., 1975. Soluções nutritivas. Summa Phytopathologica, Piracicaba, 1:231-233.

SARRUGE, J.R. e H.P.HAAG, 1974. Anālises quĩmicas em plantas. Piracicaba, ESALQ/USP. $56 \mathrm{p}$.

SELLSCHOP, J.P.F., 1962. Cowpeas, Vigna unguiculata (L.) Walp. Field Crop Abstracts, Alberystwyth, 15(4):259-266.

SINHA, H., 1961. Effects of potassium-boron interactions upon growth and composition of soybean and vegetable crops. Dissertation Abstracts, Ann Arbor, 22:1343-1344. Apud Soils and Fertilizers, Farnham Royal, 25:226, 1962 .

STAMFORD, N.P., 1978. Efeito de estirpes de Rhyzobium sp., do nitrogēnio, fósforo e enxōfre na avaliação da fixação do $\mathrm{N}_{2}$, crescimento e absorção de nutrientes em cultivares de Vigna unguiculata (L.) Walp. Piracicaba, ESALQ/USP. 151 p. (Tese de Doutoramento). 
STEWART, F.B. e M.REED, 1969. The effect of fertilization on yield, growth and mineral composition of southern peas. Journal of the American Society for Horticultural Science, St. Joseph, 94:258-260.

TAVORA, F.J.A.F.; J.F.ALVES e R.P.NUNES, 1971. Adubação fosfatada em feijão-de-corda Vigna sp. Ciência Agronōmica, Fortaleza, I (1):23-26.

WADLEIGH, C.H. e H.G.GAUCH, 1942. Assimilation in bean plants of nitrogen from saline solutions. Proceedings American Society for Horticultural. Science, College Park, Ma. 41:360-364.

WALLACE, A., S.J.TOTH e F.E.BEAR, 1948. Influence of sodium on growth and composition of ranger alfafa. Soil Science. New Brunswick, 65: $477-486$.

WORD, J.0. e J.H.SANDERS, 1977. Nutrição, renda e tecnologia nova para pequenos agricultores no nordeste brasileiro: algumas interrelações e sugestões de politicas. In: SOCIEDADE BRASILEIRA DE ECONOMIA RURAL, Viçosa. Politica agrícola e agricultura de baixa renda; anais da XV Reunião Anual. Viçosa, Universidade Federal, v.3.

WORLEY, R.E.; D.A.HEGWOOD e S.A.HARMON, 1971. Effect of nitrogen, phosphorus and potassium on yield and leaf analysis of southern pea. Journal of the American Society for Horticultural Science, St. Joseph, $96(4): 531-533$. 